\title{
openheart First-generation versus second-generation drug-eluting stents in current clinical practice: updated evidence from a comprehensive meta-analysis of randomised clinical trials comprising 31379 patients
}

To cite: Navarese EP, Kowalewski M, Kandzari D, et al. First-generation versus second-generation drugeluting stents in current clinical practice: updated evidence from a comprehensive metaanalysis of randomised clinical trials comprising 31379 patients. Open Heart 2014;1: e000064. doi:10.1136/ openhrt-2014-000064

- Additional material is available. To view please visit the journal (http://dx.doi.org/ 10.1136/openhrt-2014000064).

Received 18 February 2014 Revised 15 May 2014 Accepted 15 July 2014

\section{CrossMark}

For numbered affiliations see end of article.

Correspondence to Dr Eliano Pio Navarese; eliano.navarese@alice.it

\section{ABSTRACT}

Background: First-generation drug-eluting stents (DES) have become the most widely used devices worldwide for management of coronary artery disease. As remote follow-up data were becoming available, concerns emerged in regard to their long-term safety. Second-generation DES were designed to overcome safety issues, but the results of randomised clinical trials remain conflicting.

Methods: We compared the safety and efficacy of first-generation versus second-generation Food and Drug Administration approved DES; the following devices were included: first-generation sirolimuseluting stent (SES) and paclitaxel-eluting stents (PES); second-generation everolimus-eluting stent (EES), zotarolimus-eluting stent Endeavor and ZES-Resolute (ZES-R). Prespecified safety end points comprised $\leq 1$ and $>1$ year: overall and cardiac mortality, myocardial infarction (MI), definite/definite or probable ST; efficacy end points were target lesion revascularisation and target vessel revascularisation. Composite end points were analysed as well.

Results: 33 randomised controlled trials involving 31379 patients with stable coronary artery disease or acute coronary syndrome undergoing DES implantation were retrieved. No differences in mortality among devices were found. In the overall class comparison, second-generation DES were associated with a $22 \%$ reduction of odds of MI at short-term OR 0.77 (95\% $\mathrm{Cl} 0.68$ to 0.89 ) $p=0.0002$; EES reduced the odds of definite-probable ST compared with PES: OR 0.33 $(95 \% \mathrm{Cl} 0.15$ to 0.73$) p=0.006$; First-generation SES along with second-generation EES and ZES-R showed similar efficacy in decreasing the odds of repeat revascularisation.

Conclusions: Second-generation EES and ZES-R offer similar levels of efficacy compared with first-generation SES, but are more effective than PES; however, only

\section{KEY MESSAGES}

What is already known about this subject?

- Second generation DES are similarly effective as first generation DES.

What does this study add?

- Everolimus eluting stent was found to significantly reduce the odds of myocardial infarction and stent thrombosis.

How might this impact on clinical practice?

- No differences in mortality was found between these devices.

second-generation EES significantly reduced the incidence of MI and ST, and therefore should be perceived as the safest DES to date.

\section{INTRODUCTION}

Over the past 10 years, first-generation drugeluting stents (DES), especially sirolimuseluting stent (SES) and paclitaxel-eluting stents (PES), have become the most widely used devices worldwide for management of coronary artery disease. However, despite their clear superiority in preventing restenosis and the need for repeat revascularisation due to eluted antiproliferative drugs is certainly proven, ${ }^{1}$ as remote follow-up data were becoming available, concerns emerged in regard to their long-term safety, strictly late and very late thrombotic events, in turn associated with a high rate of death and 


\begin{tabular}{|c|c|c|c|c|c|c|c|c|c|c|c|c|}
\hline Study & Journal & Year & $\begin{array}{l}\text { Number } \\
\text { of } \\
\text { patients }\end{array}$ & $\begin{array}{l}\text { First } \\
\text { generation }\end{array}$ & $\begin{array}{l}\text { Second } \\
\text { generation }\end{array}$ & $\begin{array}{l}\text { Short-term } \\
\text { follow-up } \\
\text { ( } \leq 12 \text { months) }\end{array}$ & $\begin{array}{l}\text { Long-term } \\
\text { follow-up } \\
\text { (>12 months) }\end{array}$ & $\begin{array}{l}\text { Primary } \\
\text { end point }\end{array}$ & $\begin{array}{l}\text { MACE/TVF } \\
\text { definition }\end{array}$ & $\begin{array}{l}\text { Clinical } \\
\text { setting }\end{array}$ & $\begin{array}{l}\text { Minimal DAPT } \\
\text { duration (ADP } \\
\text { receptor/ } \\
\text { P2Y12 inhibitor) }\end{array}$ & $\begin{array}{l}\text { Protocol } \\
\text { defined } \\
\text { follow-up } \\
\text { angiography }\end{array}$ \\
\hline APPENDIX-AMI ${ }^{13} 14$ & PLOS ONE & 2013 & 977 & SES Cypher & EES Xience $\mathrm{V}$ & 12 months ${ }^{*}$ & 24 months & MACE & $\begin{array}{l}\text { Cardiac } \\
\text { mortality, MI, } \\
\text { TVR }\end{array}$ & $\begin{array}{l}\text { Stable/ } \\
\text { ACS }\end{array}$ & 12 months & No \\
\hline BASKET-PROVE $^{15}$ & NEJM & 2010 & 1549 & SES Cypher & EES Xience V & n.r. & 24 months & MACE & $\begin{array}{l}\text { Mortality, MI, } \\
\text { TVR }\end{array}$ & $\begin{array}{l}\text { Stable/ } \\
\text { ACS }\end{array}$ & 12 months & No \\
\hline CATOS $^{16}$ & Circulation Journal & 2012 & 160 & SES Cypher & $\begin{array}{l}\text { ZES } \\
\text { Endeavor }\end{array}$ & 12 months & n.r. & $\begin{array}{l}\text { In-segment binary } \\
\text { restenosis rate at } \\
9 \text { months } \\
\text { angiographic } \\
\text { follow-up }\end{array}$ & $\begin{array}{l}\text { Cardiac } \\
\text { mortality, MI, } \\
\text { TVR }\end{array}$ & Сто & 12 months & Yes \\
\hline CIBELES $^{17}$ & $\begin{array}{l}\text { Circulation } \\
\text { Cardiovascular } \\
\text { Interventions }\end{array}$ & 2013 & 207 & SES Cypher & EES Xience V & 12 months & n.r. & $\begin{array}{l}\text { In-stent late loss at } \\
9 \text { months } \\
\text { angiographic } \\
\text { follow-up }\end{array}$ & $\begin{array}{l}\text { Mortality, MI, } \\
\text { TVR }\end{array}$ & TCO & 12 months & Yes \\
\hline COMPARE $^{18-20}$ & $\begin{array}{l}\text { Lancet } \\
\text { JACC }\end{array}$ & $\begin{array}{l}2010 \\
2011\end{array}$ & 1800 & $\begin{array}{l}\text { PES Taxus } \\
\text { Liberte }\end{array}$ & EES Xience V & 12 months & 24,36 months & MACE & $\begin{array}{l}\text { Mortality, MI, } \\
\text { TVR }\end{array}$ & $\begin{array}{l}\text { Stable/ } \\
\text { ACS }\end{array}$ & 12 months & No \\
\hline ENDEAVOR \|\|$^{21} 22$ & $\begin{array}{l}\text { JACC } \\
\text { JACC } \\
\text { Cardiovascular } \\
\text { Interventions }\end{array}$ & 2006 & 436 & SES Cypher & $\begin{array}{l}\text { ZES } \\
\text { Endeavor }\end{array}$ & 9 months & 60 months & $\begin{array}{l}\text { In-segment late } \\
\text { lumen loss at } \\
8 \text { months } \\
\text { angiographic } \\
\text { follow-up }\end{array}$ & $\begin{array}{l}\text { Mortality, MI, } \\
\text { TLR }\end{array}$ & $\begin{array}{l}\text { Stable/ } \\
\text { ACS }\end{array}$ & 3 months & Yes \\
\hline ENDEAVOR IV²3 24 & $\begin{array}{l}\text { JACC } \\
\text { JACC } \\
\text { Cardiovascular } \\
\text { Interventions }\end{array}$ & $\begin{array}{l}2010 \\
2013\end{array}$ & 1548 & $\begin{array}{l}\text { PES Taxus } \\
\text { Express }\end{array}$ & $\begin{array}{l}\text { ZES } \\
\text { Endeavor }\end{array}$ & 12 months & 60 months & TVF at 9 months & $\begin{array}{l}\text { Mortality, MI, } \\
\text { TLR }\end{array}$ & $\begin{array}{l}\text { Stable/ } \\
\text { ACS }\end{array}$ & 6 months & Yes \\
\hline ESSENCE-Diabetes ${ }^{25}$ & Circulation & 2011 & 300 & SES Cypher & EES Xience V & 12 months & n.r. & $\begin{array}{l}\text { In-segment late } \\
\text { lumen loss at } \\
8 \text { months } \\
\text { angiographic } \\
\text { follow-up }\end{array}$ & $\begin{array}{l}\text { Mortality, MI, } \\
\text { TLR }\end{array}$ & $\begin{array}{l}\text { Stable/ } \\
\text { ACS }\end{array}$ & 12 months & Yes \\
\hline EXCELLENT ${ }^{26}$ & $J A C C$ & 2011 & 1428 & SES Cypher & $\begin{array}{l}\text { EES Xience V } \\
\text { or Promus }\end{array}$ & 12 months & n.r. & $\begin{array}{l}\text { In-segment late } \\
\text { lumen loss at } \\
9 \text { months } \\
\text { angiographic } \\
\text { follow-up }\end{array}$ & $\begin{array}{l}\text { Cardiac } \\
\text { mortality, MI, } \\
\text { TLR }\end{array}$ & $\begin{array}{l}\text { Stable/ } \\
\text { ACS }\end{array}$ & 6 months & Yes \\
\hline EXECUTIVE $^{27}$ & $\begin{array}{l}\text { JACC } \\
\text { Cardiovascular } \\
\text { Interventions }\end{array}$ & 2013 & 200 & $\begin{array}{l}\text { PES Taxus } \\
\text { Liberte }\end{array}$ & EES Xience V & 12 months & n.r. & $\begin{array}{l}\text { In-segment late } \\
\text { lumen loss at } \\
9 \text { months } \\
\text { angiographic } \\
\text { follow-up }\end{array}$ & $\begin{array}{l}\text { Mortality, MI, } \\
\text { TVR }\end{array}$ & $\begin{array}{l}\text { Stable/ } \\
\text { ACS }\end{array}$ & 6 months & Yes \\
\hline ISAR-TEST-2 2829 & $\begin{array}{l}E H J \\
J A C C\end{array}$ & $\begin{array}{l}2009 \\
2010\end{array}$ & 674 & SES Cypher & $\begin{array}{l}\text { ZES } \\
\text { Endeavor }\end{array}$ & 12 months & 24 months & $\begin{array}{l}\text { binary angiographic } \\
\text { restenosis at } 6- \\
\text { 8-month follow-up } \\
\text { angiography }\end{array}$ & $\begin{array}{l}\text { Mortality, MI, } \\
\text { TLR }\end{array}$ & $\begin{array}{l}\text { Stable/ } \\
\text { ACS }\end{array}$ & 12 months & Yes \\
\hline KOMER $^{30}$ & Eurolntervention & 2011 & 611 & $\begin{array}{l}\text { SES Cypher } \\
\text { and PES Taxus } \\
\text { Express }\end{array}$ & $\begin{array}{l}\text { ZES } \\
\text { Endeavor }\end{array}$ & 12 months & 18 months & MACE & $\begin{array}{l}\text { Cardiac } \\
\text { mortality, MI, } \\
\text { TLR }\end{array}$ & STEMI & 12 months & Yes \\
\hline
\end{tabular}




\begin{tabular}{|c|c|c|c|c|c|c|c|c|c|c|c|c|}
\hline Study & Journal & Year & $\begin{array}{l}\text { Number } \\
\text { of } \\
\text { patients }\end{array}$ & $\begin{array}{l}\text { First } \\
\text { generation }\end{array}$ & $\begin{array}{l}\text { Second } \\
\text { generation }\end{array}$ & $\begin{array}{l}\text { Short-term } \\
\text { follow-up } \\
\text { ( } \leq 12 \text { months) }\end{array}$ & $\begin{array}{l}\text { Long-term } \\
\text { follow-up } \\
\text { (>12 months) }\end{array}$ & $\begin{array}{l}\text { Primary } \\
\text { end point }\end{array}$ & $\begin{array}{l}\text { MACE/TVF } \\
\text { definition }\end{array}$ & $\begin{array}{l}\text { Clinical } \\
\text { setting }\end{array}$ & $\begin{array}{l}\text { Minimal DAPT } \\
\text { duration (ADP } \\
\text { receptor/ } \\
\text { P2Y12 inhibitor) }\end{array}$ & $\begin{array}{l}\text { Protocol } \\
\text { defined } \\
\text { follow-up } \\
\text { angiography }\end{array}$ \\
\hline LONG-DES $\|^{31}$ & $J A C C$ & 2011 & 450 & SES Cypher & $\begin{array}{l}\text { EES Xience V } \\
\text { or Promus }\end{array}$ & 12 months & n.r. & $\begin{array}{l}\text { In-segment late } \\
\text { lumen loss at } \\
9 \text { months } \\
\text { angiographic } \\
\text { follow-up }\end{array}$ & $\begin{array}{l}\text { Mortality, MI, } \\
\text { TVR }\end{array}$ & $\begin{array}{l}\text { Stable/ } \\
\text { ACS }\end{array}$ & 12 months & Yes \\
\hline LONG-DES IV ${ }^{32}$ & $\begin{array}{l}\text { Circulation } \\
\text { Cardiovascular } \\
\text { Interventions }\end{array}$ & 2012 & 500 & SES Cypher & ZES Resolute & 12 months & n.r. & $\begin{array}{l}\text { In-segment late } \\
\text { lumen loss at } \\
9 \text { months } \\
\text { angiographic } \\
\text { follow-up }\end{array}$ & $\begin{array}{l}\text { Mortality, MI, } \\
\text { TVR }\end{array}$ & $\begin{array}{l}\text { Stable/ } \\
\text { ACS }\end{array}$ & 12 months & Yes \\
\hline Naples-Diabetes $^{33}$ & $\begin{array}{l}\text { Circulation } \\
\text { Cardiovascular } \\
\text { Interventions }\end{array}$ & 2011 & 226 & $\begin{array}{l}\text { SES Cypher } \\
\text { and PES Taxus } \\
\text { Liberte }\end{array}$ & $\begin{array}{l}\text { ZES } \\
\text { Endeavor }\end{array}$ & $\begin{array}{l}\text { In-hospital; } \\
12 \text { months }\end{array}$ & 36 months & MACE & $\begin{array}{l}\text { Mortality, MI, } \\
\text { TVR }\end{array}$ & $\begin{array}{l}\text { Stable/ } \\
\text { ACS }\end{array}$ & 6 months & No \\
\hline PRISON III ${ }^{34}$ & Eurolntervention & 2013 & 304 & SES Cypher & $\begin{array}{l}\text { ZES Resolute } \\
\text { or ZES } \\
\text { Endeavor }\end{array}$ & 12 months & n.r. & $\begin{array}{l}\text { In-segment late } \\
\text { lumen loss at } \\
8 \text { months } \\
\text { angiographic } \\
\text { follow-up }\end{array}$ & $\begin{array}{l}\text { Mortality, MI, } \\
\text { TLR }\end{array}$ & TCO & 12 months & Yes \\
\hline R-CHINA RCT ${ }^{35}$ & $\begin{array}{l}\text { JACC } \\
\text { Cardiovascular } \\
\text { Interventions }\end{array}$ & 2013 & 400 & $\begin{array}{l}\text { PES Taxus } \\
\text { Liberte }\end{array}$ & ZES Resolute & 12 months & n.r. & $\begin{array}{l}\text { In-stent late lumen } \\
\text { loss at } 9 \text { months } \\
\text { angiographic } \\
\text { follow-up }\end{array}$ & $\begin{array}{l}\text { Mortality, MI, } \\
\text { TLR }\end{array}$ & $\begin{array}{l}\text { Stable/ } \\
\text { ACS }\end{array}$ & 6 months & Yes \\
\hline RESET ${ }^{36}$ & Circulation & 2012 & 3197 & SES Cypher & EES Xience V & 12 months & n.r. & $\begin{array}{l}\text { TLR at } 12 \text { months; } \\
\text { composite of } \\
\text { all-cause death and } \\
\text { Ml at } 36 \text { months }\end{array}$ & $\begin{array}{l}\text { Cardiac } \\
\text { mortality, MI, } \\
\text { TLR }\end{array}$ & $\begin{array}{l}\text { Stable/ } \\
\text { ACS }\end{array}$ & 3 months & No \\
\hline Sakakibara et $a \beta^{37}$ & Circulation Journal & 2012 & 100 & SES Cypher & EES Xience V & 12 months & n.r. & $\begin{array}{l}\text { binary angiographic } \\
\text { restenosis at } 8 \text { month } \\
\text { follow-up } \\
\text { angiography }\end{array}$ & $\begin{array}{l}\text { Mortality, MI, } \\
\text { TLR }\end{array}$ & Stable & 12 months & Yes \\
\hline Sawada et $\left.a\right|^{\beta 8}$ & $\begin{array}{l}\text { International } \\
\text { Journal of } \\
\text { Cardiology }\end{array}$ & 2012 & 35 & SES Cypher & $\begin{array}{l}\text { EES Xience V } \\
\text { or Promus }\end{array}$ & 7 months & n.r. & $\begin{array}{l}\text { Neointimal thickness } \\
\text { and ST }\end{array}$ & n.a. & STEMI & 7 months & Yes \\
\hline SEA-SIDE ${ }^{39}$ & $\begin{array}{l}\text { JACC } \\
\text { Cardiovascular } \\
\text { Interventions }\end{array}$ & 2011 & 150 & SES Cypher & EES Xience V & n.r. & 18 months & $\begin{array}{l}\text { Occurrence of any } \\
\text { trouble in the } \\
\text { side-branch (SB) } \\
\text { management }\end{array}$ & $\begin{array}{l}\text { Mortality, MI, } \\
\text { TVR }\end{array}$ & $\begin{array}{l}\text { Stable/ } \\
\text { ACS }\end{array}$ & 12 months & No \\
\hline $\mathrm{SEZE}^{40}$ & $\begin{array}{l}\text { Chinese Medical } \\
\text { Journal }\end{array}$ & 2012 & 122 & SES Cypher & $\begin{array}{l}\text { ZES } \\
\text { Endeavor }\end{array}$ & 12 months & n.r. & $\begin{array}{l}\text { In-stent late lumen } \\
\text { loss at } 9 \text { months } \\
\text { angiographic } \\
\text { follow-up }\end{array}$ & $\begin{array}{l}\text { Cardiac } \\
\text { mortality, MI, } \\
\text { TVR }\end{array}$ & STEMI & 12 months & Yes \\
\hline Song et $a l^{41}$ & $J A C C$ & 2012 & 1114 & SES Cypher & EES Xience V & 12 months & n.r. & $\begin{array}{l}\text { In-segment late } \\
\text { lumen loss at } \\
9 \text { months } \\
\text { angiographic } \\
\text { follow-up }\end{array}$ & $\begin{array}{l}\text { Mortality, MI, } \\
\text { TVR }\end{array}$ & $\begin{array}{l}\text { Stable/ } \\
\text { ACS }\end{array}$ & 6 months & Yes \\
\hline
\end{tabular}




\begin{tabular}{|c|c|c|c|c|c|c|c|c|c|c|c|c|}
\hline Study & Journal & Year & $\begin{array}{l}\text { Number } \\
\text { of } \\
\text { patients }\end{array}$ & $\begin{array}{l}\text { First } \\
\text { generation }\end{array}$ & $\begin{array}{l}\text { Second } \\
\text { generation }\end{array}$ & $\begin{array}{l}\text { Short-term } \\
\text { follow-up } \\
\text { ( } \leq 12 \text { months) }\end{array}$ & $\begin{array}{l}\text { Long-term } \\
\text { follow-up } \\
\text { (>12 months) }\end{array}$ & $\begin{array}{l}\text { Primary } \\
\text { end point }\end{array}$ & $\begin{array}{l}\text { MACE/TVF } \\
\text { definition }\end{array}$ & $\begin{array}{l}\text { Clinical } \\
\text { setting }\end{array}$ & $\begin{array}{l}\text { Minimal DAPT } \\
\text { duration (ADP } \\
\text { receptor/ } \\
\text { P2Y12 inhibitor) }\end{array}$ & $\begin{array}{l}\text { Protocol } \\
\text { defined } \\
\text { follow-up } \\
\text { angiography }\end{array}$ \\
\hline SORT OUT IIII243 & $\begin{array}{l}\text { Lancet } \\
\text { JACC } \\
\text { Cardiovascular } \\
\text { Interventions }\end{array}$ & $\begin{array}{l}2010 \\
2013\end{array}$ & 2332 & SES Cypher & $\begin{array}{l}\text { ZES } \\
\text { Endeavor }\end{array}$ & 9 months & 36 months & MACE & $\begin{array}{l}\text { Cardiac } \\
\text { mortality, MI, } \\
\text { TVR }\end{array}$ & $\begin{array}{l}\text { Stable/ } \\
\text { ACS }\end{array}$ & 12 months & No \\
\hline SORT OUT IV 4445 & $\begin{array}{l}\text { Circulation } \\
\text { JACC }\end{array}$ & $\begin{array}{l}2012 \\
2012\end{array}$ & 2774 & SES Cypher & $\begin{array}{l}\text { EES Xience V } \\
\text { or Promus }\end{array}$ & 9 months & $\begin{array}{l}24,36 \\
\text { [ref-tctmd] } \\
\text { months }\end{array}$ & MACE & $\begin{array}{l}\text { Cardiac } \\
\text { mortality, MI, } \\
\text { TVR, def. ST }\end{array}$ & $\begin{array}{l}\text { Stable/ } \\
\text { ACS }\end{array}$ & 12 months & No \\
\hline SPIRIT II ${ }^{46} 47$ & $\begin{array}{l}\text { EuroIntervention } \\
\text { EuroIntervention }\end{array}$ & $\begin{array}{l}2007 \\
2012\end{array}$ & 300 & $\begin{array}{l}\text { PES Taxus } \\
\text { Liberte or PES } \\
\text { Taxus Express }\end{array}$ & EES Xience V & 12 months & 60 months & $\begin{array}{l}\text { In-stent late lumen } \\
\text { loss at } 6 \text { months } \\
\text { angiographic } \\
\text { follow-up }\end{array}$ & $\begin{array}{l}\text { Cardiac } \\
\text { mortality, MI, } \\
\text { TLR }\end{array}$ & $\begin{array}{l}\text { Stable/ } \\
\text { ACS }\end{array}$ & 12 months & Yes \\
\hline SPIRIT IIII 49 & $\begin{array}{l}\text { JAMA } \\
\text { The American } \\
\text { Journal of } \\
\text { Cardiology }\end{array}$ & $\begin{array}{l}2008 \\
2011\end{array}$ & 1001 & $\begin{array}{l}\text { PES Taxus } \\
\text { Express }\end{array}$ & EES Xience V & 12 months & $\begin{array}{l}36,60 \text { [ref } \\
\text { stone ppt] } \\
\text { months }\end{array}$ & $\begin{array}{l}\text { In-stent late lumen } \\
\text { loss at } 8 \text { months } \\
\text { angiographic } \\
\text { follow-up }\end{array}$ & $\begin{array}{l}\text { Cardiac } \\
\text { mortality, MI, } \\
\text { TLR }\end{array}$ & $\begin{array}{l}\text { Stable/ } \\
\text { ACS }\end{array}$ & 6 months & Yes \\
\hline SPIRIT IV 5051 & $\begin{array}{l}\text { NEJM } \\
\text { JACC }\end{array}$ & $\begin{array}{l}2010 \\
2011\end{array}$ & 3687 & $\begin{array}{l}\text { PES Taxus } \\
\text { Express }\end{array}$ & EES Xience V & 12 months & 24 months & $\begin{array}{l}\text { Composite of cardiac } \\
\text { death, target vessel } \\
\text { MI and TLR }\end{array}$ & $\begin{array}{l}\text { Cardiac } \\
\text { mortality, MI, } \\
\text { TLR }\end{array}$ & $\begin{array}{l}\text { Stable/ } \\
\text { ACS }\end{array}$ & 12 months & No \\
\hline $\begin{array}{l}\text { SPIRIT V Diabetic } \\
\text { Study }\end{array}$ & $\begin{array}{l}\text { American Heart } \\
\text { Journal }\end{array}$ & 2012 & 324 & $\begin{array}{l}\text { PES Taxus } \\
\text { Liberte }\end{array}$ & EES Xience V & 12 months & n.r. & $\begin{array}{l}\text { In-stent late lumen } \\
\text { loss at } 9 \text { months } \\
\text { angiographic } \\
\text { follow-up }\end{array}$ & $\begin{array}{l}\text { Mortality, MI, } \\
\text { TVR }\end{array}$ & $\begin{array}{l}\text { Stable/ } \\
\text { ACS }\end{array}$ & 6 months & Yes \\
\hline Wang et $a^{\rho^{3}}$ & JACC abstracts & 2011 & 875 & SES Cypher & $\begin{array}{l}\text { ZES } \\
\text { Endeavor }\end{array}$ & 6 months & n.r. & MACE & $\begin{array}{l}\text { Cardiac } \\
\text { mortality, MI, } \\
\text { TLR }\end{array}$ & STEMI & n.r. & No \\
\hline $\mathrm{XAMI}^{54}$ & $J A C C$ & 2012 & 625 & SES Cypher & EES Xience V & 12 months & n.r. & MACE & $\begin{array}{l}\text { Cardiac } \\
\text { mortality, MI, } \\
\text { TVR }\end{array}$ & STEMI & 12 months & No \\
\hline ZEST ${ }^{55}$ & $J A C C$ & 2010 & 2645 & $\begin{array}{l}\text { SES Cypher or } \\
\text { PES Taxus } \\
\text { Liberte }\end{array}$ & $\begin{array}{l}\text { ZES } \\
\text { Endeavor }\end{array}$ & 12 months & n.r. & MACE & $\begin{array}{l}\text { Mortality, MI, } \\
\text { TVR }\end{array}$ & $\begin{array}{l}\text { Stable/ } \\
\text { ACS }\end{array}$ & 12 months & Yes \\
\hline ZEST-AMI $^{5657}$ & $\begin{array}{l}\text { The American } \\
\text { Journal of } \\
\text { Cardiology }\end{array}$ & 2009 & 328 & $\begin{array}{l}\text { SES Cypher or } \\
\text { PES Taxus } \\
\text { Liberte }\end{array}$ & $\begin{array}{l}\text { ZES } \\
\text { Endeavor }\end{array}$ & 12 months & n.r. & MACE & $\begin{array}{l}\text { Mortality, MI, } \\
\text { TVR }\end{array}$ & STEMI & 12 months & Yes \\
\hline
\end{tabular}

ACS, acute coronary syndrome; DAPT, dual antiplatelet therapy; EES, everolimus-eluting stent; MACE, major adverse cardiovascular events; MI, myocardial infarction; PES, paclitaxel-eluting stent; SES, sirolimus-eluting stent; STEMI, ST elevation myocardial infarction; TLR, target lesion revascularisation; TVR, target vessel revascularisation; ZES, zotarolimus-eluting stent. 
myocardial infarction (MI). ${ }^{2}{ }^{3}$ Such events have been attributed to the incomplete re-endothelialisation caused by the drug-induced inhibition of endothelial cell proliferation, stent malapposition, accelerated neoatherosclerosis and, importantly, polymer-induced prolonged vessel wall inflammation. ${ }^{4}$ Second-generation DES were designed to overcome safety issues in the long term, employing new biocompatible polymer coatings, less toxic antiproliferative drugs and eventually state-of-the-art thin strut Co-Cr metal alloys, and extensively tested in randomised clinical trials (RCTs). The everolimus-eluting stent (EES) has been found to be safer than first-generation and biodegradable DES; ${ }^{5}$ on the other hand, zotarolimus-eluting stent (ZES) was inferior to SES in terms of major adverse cardiac events (MACE) and superior to PES in terms of MI in independent recent meta-analyses of RCTs. ${ }^{6} 7$

Driven by conflicting evidence on first-generation versus second-generation DES performance in regard to efficacy and safety along with another recent meta-analysis ${ }^{8}$ showing significant outcomes in one comparison only (ST rates reduction with second-generation EES vs first-generation PES, we performed a comprehensive and updated meta-analysis of all relevant DES data published to date comparing first-generation and second-generation DES in clinical practice.

\section{METHODS}

We compared the safety and efficacy of first-generation vs second-generation Food and Drug Administration (FDA) approved DES; the following devices were included: firstgeneration SES and PES, 2) second-generation EES, ZES-Endeavor ( ZES-E) and ZES-Resolute (ZES-R).

Established methods were used in adherence to the Preferred Reporting Items for Systematic reviews and Meta-Analyses (PRISMA) statement for reporting systematic reviews and meta-analyses in healthcare interventions. ${ }^{9}$ Relevant RCTs were searched until September 2013 through MEDLINE, the Cochrane Central Register of Controlled Trials (CENTRAL), Google Scholar and EMBASE databases and through http://www.tctmd.com, http://www.clinicaltrials.gov, http://www.clinicaltrialresults. org and http://www.cardiosource.com websites; documents accessible through the FDA website were scrutinised as well. The following keywords were used: "randomized trials", "drug-eluting stent", "durable polymer stent", "sirolimus stent", "paclitaxel stent", "everolimus stent", "zotarolimus stent", "Endeavor zotarolimus-stent", "Resolute zotarolimus-stent". No language, date or publication status restrictions were imposed. For each RCT, the most updated or most inclusive data were used.

Citations were screened at the title/abstract level and retrieved as full reports. Inclusion criteria were: (1)

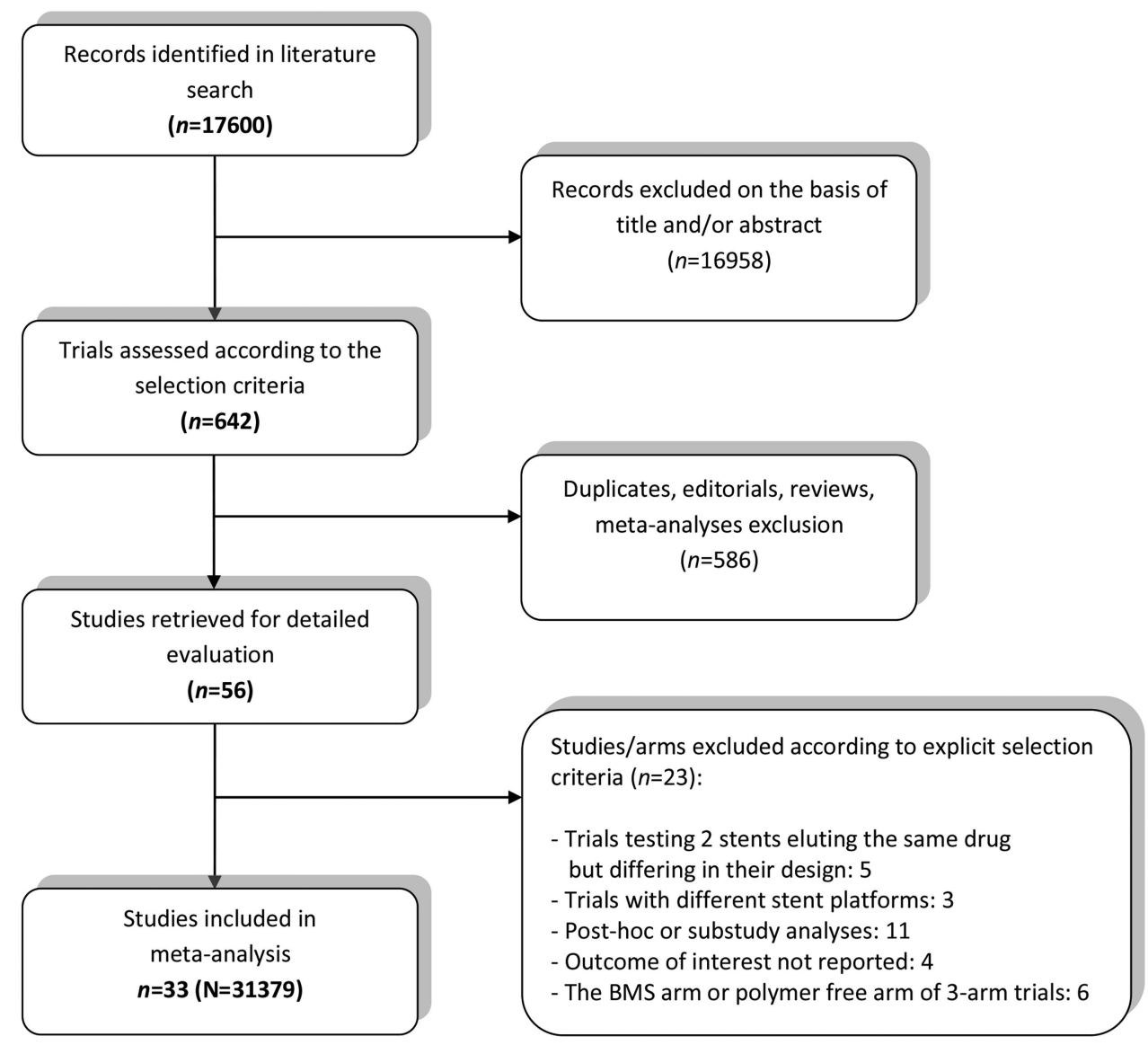

Figure 1 Flow diagram of the review process according to the Preferred Reporting Items for Systematic reviews and Meta-Analyses (PRISMA) statement. 


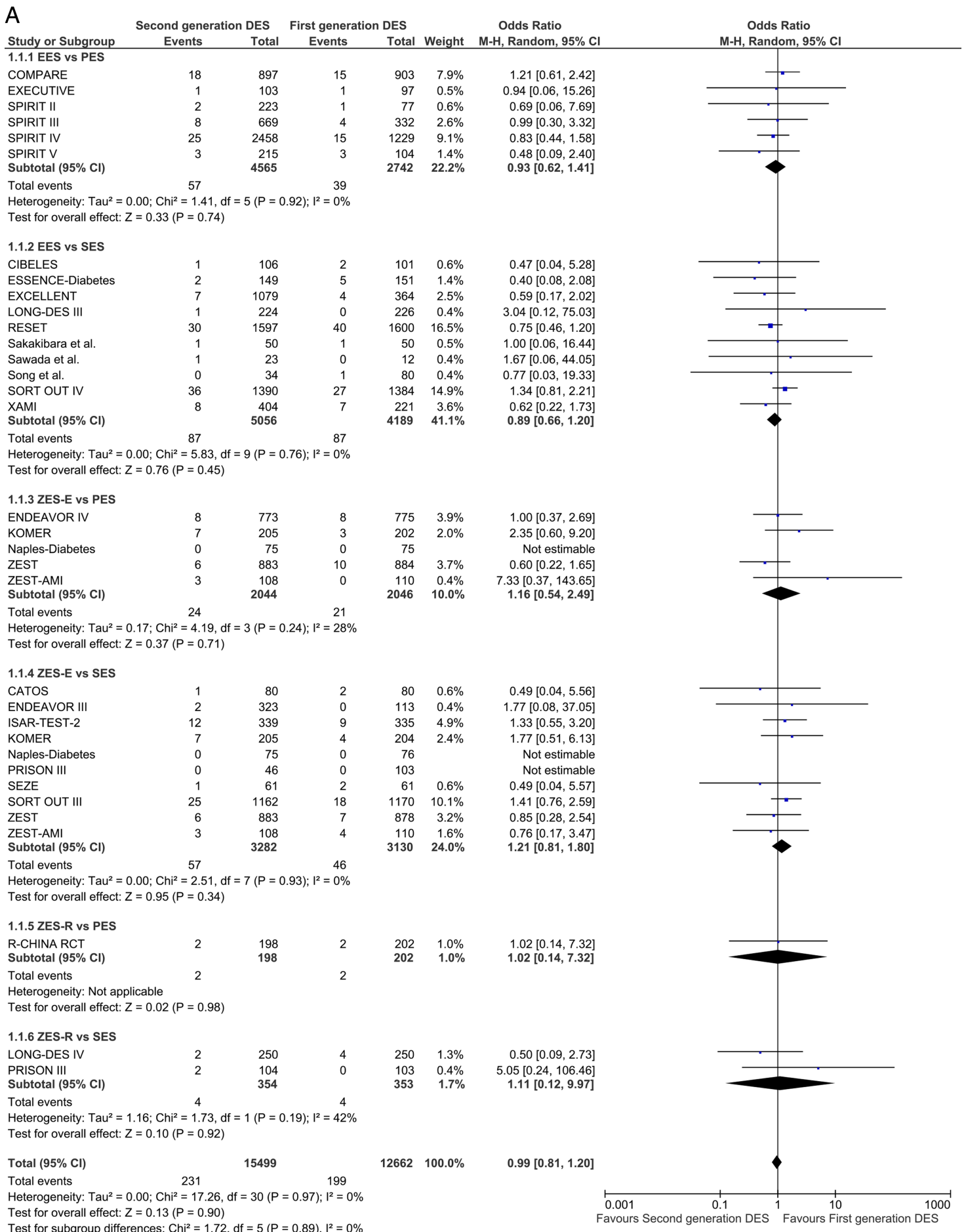

Figure 2 Analysis of all-cause mortality at short-term (A) and long-term (B) follow-up. ORs and $95 \%$ Cls. Size of squares is proportional to the statistical weight of each trial.

human studies; (2) RCTs; (3) studies comparing safety AND/OR efficacy of first-generation versus secondgeneration durable polymer DES; (4) additional data from retrieved studies available at a longer follow-up. Exclusion criteria were: (1) non-RCTs; (2) a substudy of RCTs; (3) a bare metal stent (BMS), biodegradable/ bioabsorbable stent or polymer-free stent as the control group, (4) RCTs comparing DES within their class.
Internal validity was appraised according to the proper allocation sequence/concealment, patient blinding, investigator blinding and complete outcome data/full reporting.

Prespecified safety end points comprised $\leq 1$ year: overall and cardiac mortality, MI and definite/definite or probable ST according to the definition criteria of the Academic Research Consortium (ARC) ${ }^{10}$ Efficacy 


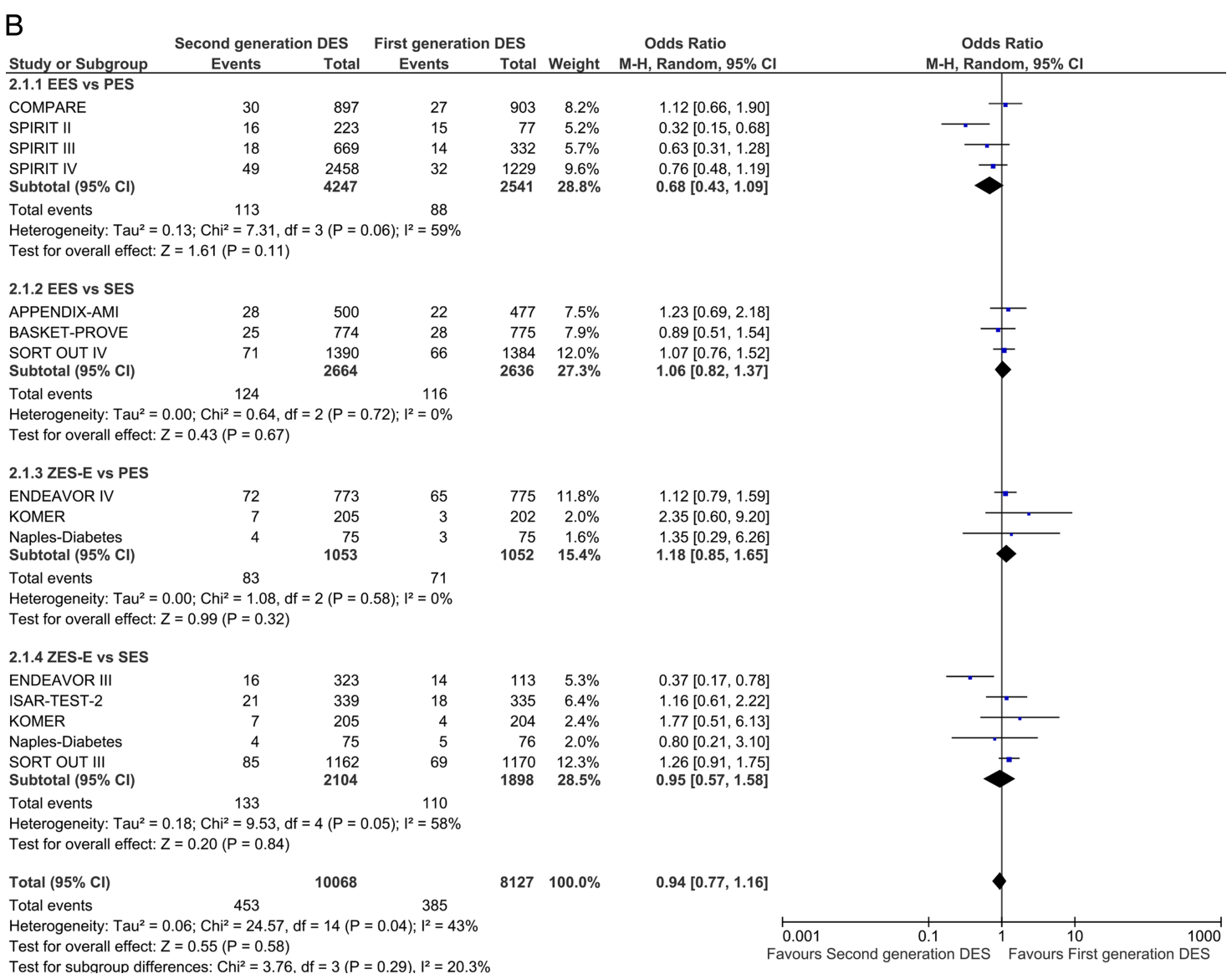

Figure 2 Continued

end points were target lesion revascularisation (TLR) and target vessel revascularisation (TVR). We also analysed the composite end point of MACE to appreciate the cumulative effect of combining non-frequent safety and efficacy adverse events; the MACE definition of each individual study was accepted, although it varied across studies (table 1). To account for over time changes in both the DES properties and eluted drug release kinetics, analyses of each clinical outcome were repeated at longest available, beyond 1 year follow-up.

\section{Statistical analysis}

Data were analysed according to the intention-to-treat principle. ORs and $95 \%$ CIs were used as summary statistics. Heterogeneity was assessed by the Cochran $Q$ test. Statistical heterogeneity was summarised by the $\mathrm{I}^{2}$ statistic, which quantifies the percentage of variation in study results that is due to heterogeneity rather than chance. ${ }^{11}$ Pooled ORs were calculated using a fixed effect model with the Mantel-Haenszel method. The random effects model was applied in case of significant heterogeneity and/or moderate or significant inconsistency (heterogeneity $>50 \%$; inconsistency $\mathrm{p} \leq 0.05)$ across studies. ${ }^{12}$ Results were considered statistically significant at two-sided $p \leq 0.05$. All pooling analyses were conducted using Review Manager 5.1 (Cochrane Collaboration, Copenhagen, Denmark).

\section{RESULTS}

\section{Studies and patient population}

The PRISMA flow diagram of the studies selection is presented in figure 1 . The full electronic MEDLINE database search process along with inclusion/exclusion criteria and risk of bias analysis of included studies is shown in the online supplementary material. Thirty-three ${ }^{13-57}$ trials comprising a total of 31379 patients met the inclusion criteria and entered the analysis. Information on stent comparators, clinical setting, minimal DAPT duration and primary end points is delineated in table 1. Most trials enrolled high-risk patients with stable coronary artery disease and acute coronary syndrome presentations, with six trials restricting their inclusion criteria to STEMI patients only ${ }^{30} 3840535456$; clopidogrel was administered across all studies; the composite end point of MACE was similar throughout the studies and included cardiac death, MI and repeat revascularisation; detailed definitions are listed in table 1. Funnel plots did not reveal publication bias or small study effect and are included in the online supplementary material (see online supplementary figure S1A, B).

\section{Mortality, cardiac death}

Twenty-nine studies contributed to the analysis of $\leq 1$ year mortality. Second-generation DES were associated with results that did not differ significantly from 


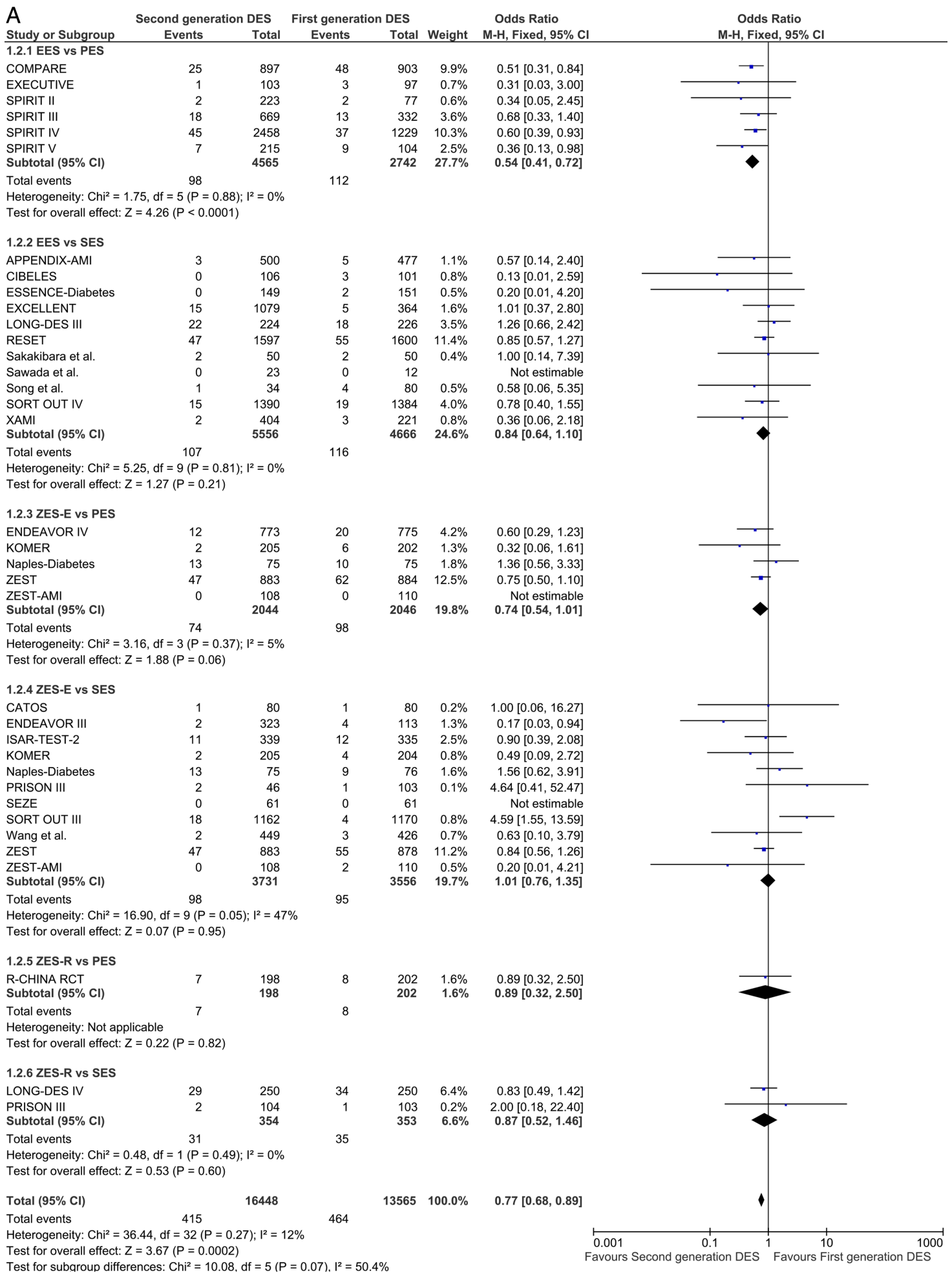

Figure 3 Analysis of Ml at short-term (A) and long-term (B) follow-up. ORs and 95\% Cls. Size of squares is proportional to the statistical weight of each trial. Ml, myocardial infarction.

those of the first-generation in either comparison group: OR 0.99 (95\% CI 0.81 to 1.20 ) $\mathrm{p}=0.90$. Results in the long term (13 studies included) were consistent with the short-term analysis: OR 0.94 (95\% CI 0.77 to 1.16 ) $\mathrm{p}=0.58$ (figure 2A). A non-significant trend favouring EES was shown in comparison with PES in the long term: OR 0.68 (95\% CI 0.43 to 1.09 ) p=0.06 (figure $2 \mathrm{~B}$ ).
The cardiac mortality analysis did not diverge from the findings from all-cause death calculations with $O R$ $1.03(95 \%$ CI 0.81 to 1.31$) \mathrm{p}=0.79$ and OR $1.02(95 \%$ CI 0.79 to 1.31$) \mathrm{p}=0.89$, for short-term and long-term follow-up, respectively, for overall first-generation versus second-generation stents comparison (see online supplementary figure S2A,B). 


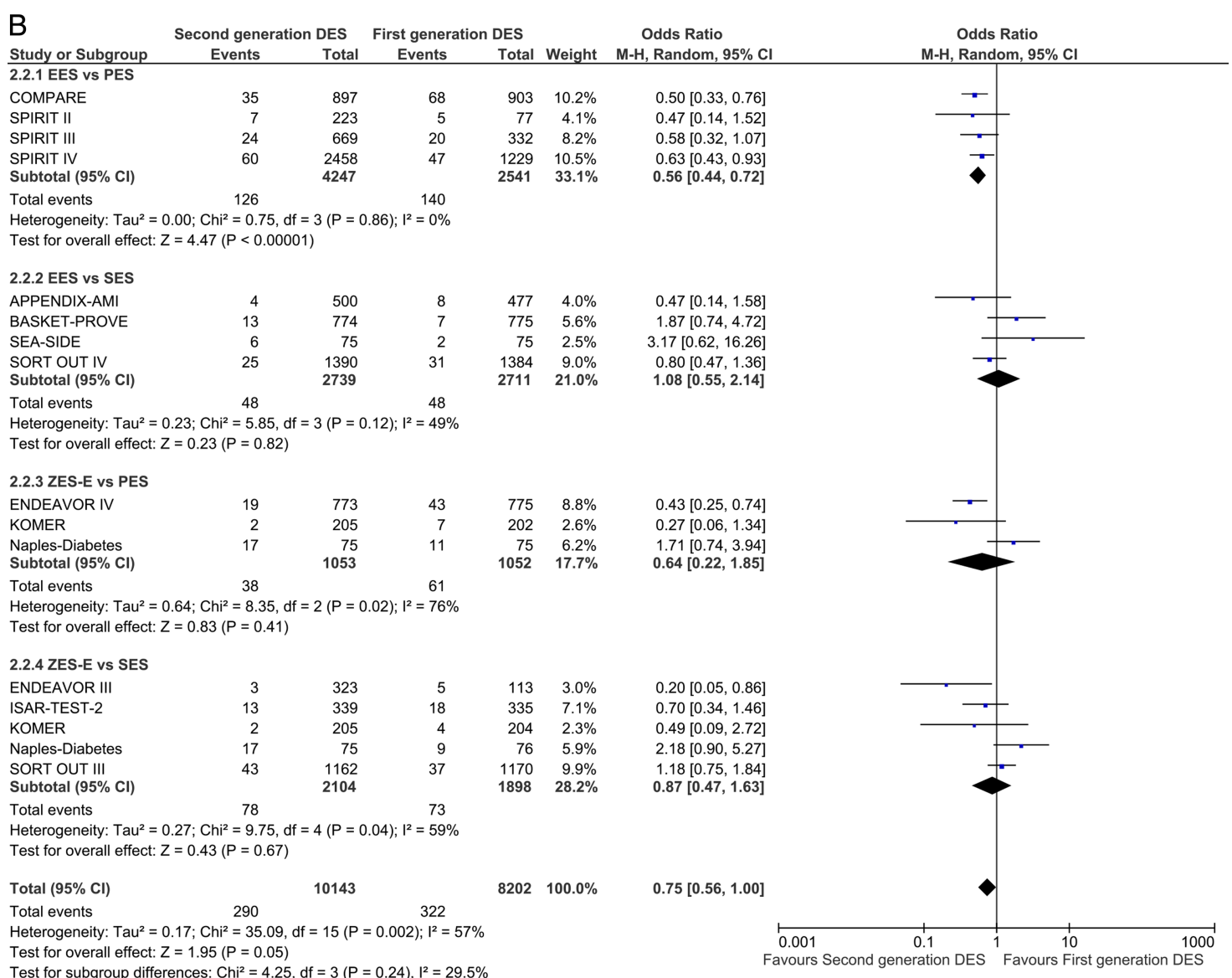

Figure 3 Continued

\section{Myocardial infarction}

Thirty-one studies were included in the MI analysis in the short term. EES significantly reduced the odds of MI compared with PES: OR 0.54 (95\% CI 0.41 to 0.72) $\mathrm{p}<0.0001$ (figure $3 \mathrm{~A}$ ). In the overall class comparison, second-generation DES were associated with a $23 \%$ reduction of odds of MI OR 0.77 (95\% CI 0.68 to 0.89 ) $\mathrm{p}=0.0002$ in the short term. A significant class effect favouring second-generation DES was sustained in the long-term analysis: OR 0.75 (95\% CI 0.56 to 1.00) $\mathrm{p}=0.05$, with the odds of MI halved in comparison with EES versus PES: OR 0.56 (95\% CI 0.44 to 0.72 ) $\mathrm{p}<0.001$ (figure 3B).

\section{Stent thrombosis}

For the analysis of definite ST, 26 studies were included. In the short term, EES was associated with significant reduction of odds of ST compared with PES and SES: OR 0.34 (95\% CI 0.18 to 0.62 ) $\mathrm{p}=0.0005$ and OR 0.43 (95\% CI 0.22 to 0.84$) \mathrm{p}=0.01$, respectively (figure $4 \mathrm{~A}$ ). Second-generation ZES-E increased the odds of ST by $122 \%$ compared with first-generation SES: OR 2.22 (95\% CI 1.14 to 4.31 ) $\mathrm{p}=0.02$. Results in the long term confirmed short follow-up findings; EES was associated with a more pronounced and significant reduction of odds of ST over time as compared with PES and SES:
OR 0.26 (95\% CI 0.14 to 0.49 ) $\mathrm{p}<0.0001$ and OR 0.30 ( $95 \%$ CI 0.11 to 0.78$) \mathrm{p}=0.01$, respectively (figure $4 \mathrm{~B}$ ).

Analysis of definite-probable ST reflected the direction of the definite ST estimates. EES reduced the odds of definite-probable ST compared with PES and SES: OR 0.33 (95\% CI 0.15 to 0.73$) \mathrm{p}=0.006$ and OR 0.61 (95\% CI 0.37 to 1.01 ) $\mathrm{p}=0.05$ (see online supplementary figure 3A). Also, at long-term follow-up, a significant reduction of definite-probable ST odds was observed with EES versus PES (OR 0.32 (95\% CI 0.17 to 0.59 ) $\mathrm{p}=0.0002$ ) and versus SES (OR 0.50 (95\% CI 0.28 to 0.88 ) $\mathrm{p}=0.02$; see online supplementary figure $3 \mathrm{~B}$ ). The overall class comparison of definite-probable ST favoured secondgeneration DES over SES at both short-term (OR 0.67 (95\% CI 0.47 to 0.94$) \mathrm{p}=0.02$ ) and long-term (OR 0.54 (95\% CI 0.37 to 0.80$) \mathrm{p}=0.002$ ) follow-up.

\section{Repeat revascularisation TLR/TVR}

Twenty-nine studies reported TLR incidence at shortterm follow-up. First-generation SES along with secondgeneration EES and ZES-R showed a similar degree of efficacy in decreasing the odds of TLR. EES reduced the odds of TLR by $43 \%$ compared with PES (OR 0.57 (95\% CI 0.36 to 0.91$) \mathrm{p}=0.02$ ) and ZES-E markedly increased the odds in comparison to SES (OR 2.61 (95\% CI 1.97 to 3.46$) \mathrm{p}<0.00001$; figure $5 \mathrm{~A}$ ), with direction and significance of the estimates being sustained 


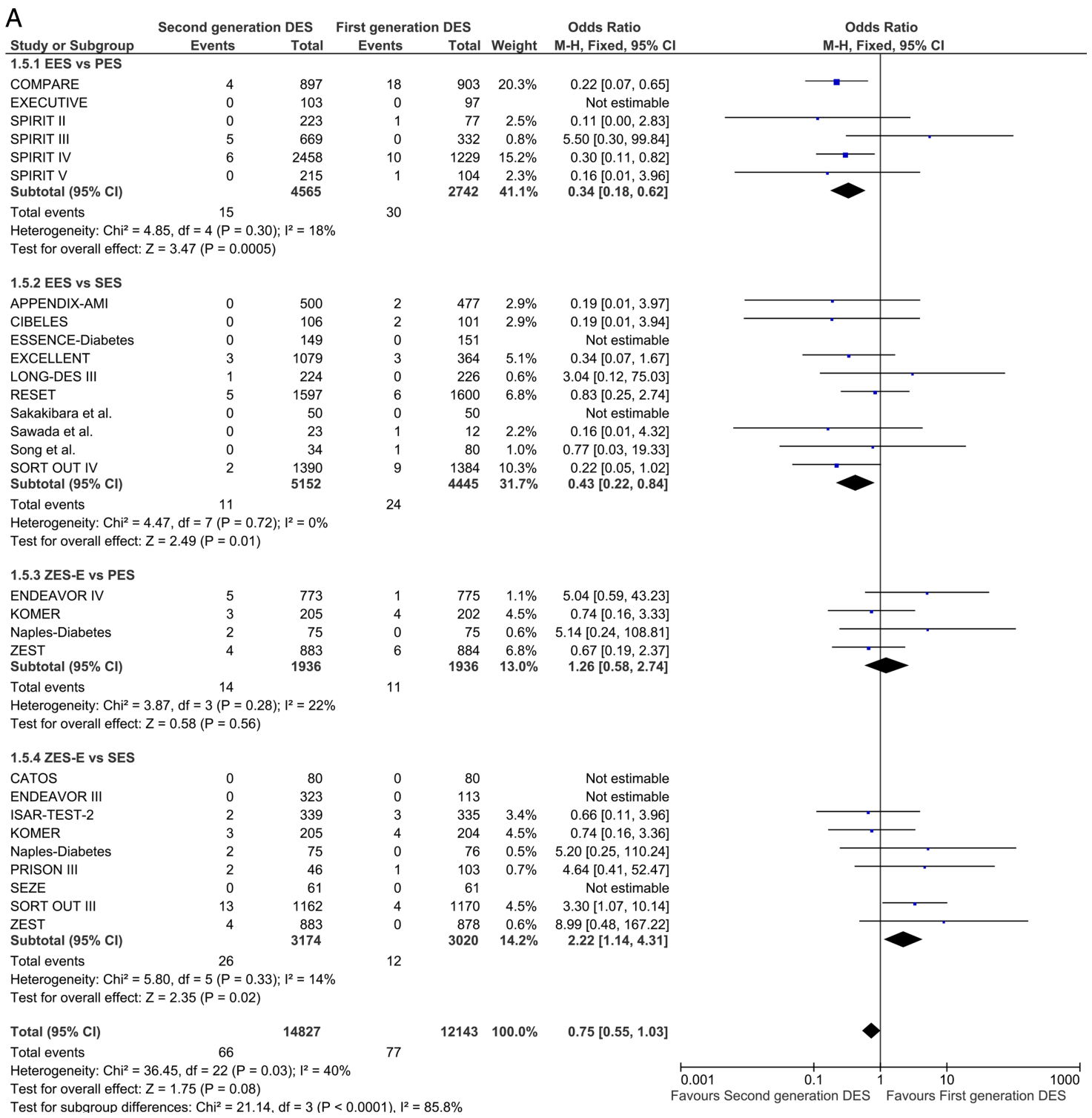

Figure 4 Analysis of definite ST at short-term (A) and long-term (B) follow-up. ORs and 95\% Cls. Size of squares is proportional to the statistical weight of each trial. ST, stent thrombosis.

over long-term follow-up (12 studies; EES vs PES: OR 0.57 (95\% CI 0.46 to 0.72$) \mathrm{p}<0.00001$; and ZES-E vs SES: OR 1.85 (95\% CI 1.18 to 2.89) $\mathrm{p}=0.007$; figure $5 \mathrm{~B}$ ).

TVR calculations were in line with those of TLR, confirming a similar high efficacy of EES, SES and ZES-R but not ZES-E or PES at both short-term and long-term follow-up (see online supplementary figure S4A,B).

\section{Major adverse cardiac events}

The analysis of composite end point of MACE included 31 studies at short-term and 13 at long-term follow-up. EES and ZES-R were found to be significantly superior to PES (OR 0.63 (95\% CI 0.52 to 0.76 ) $\mathrm{p}<0.00001$ and OR 0.44 (95\% CI 0.21 to 0.92$) \mathrm{p}=0.03)$ and ZES-E performed significantly worse than SES (OR 1.41 (95\% CI 1.13 to 1.76$) \mathrm{p}=0.002$ ) in reducing the odds of MACE at $\leq 1$ year (figure $6 \mathrm{~A}$ ). Long-term follow-up confirmed the direction and magnitude of the estimates with
EES reducing the odds of MACE by $37 \%$ compared with PES (OR 0.63 (95\% CI 0.54 to 0.73 ) p $<0.00001$; figure $6 \mathrm{~B}$ )

\section{Sensitivity analyses}

Prespecified sensitivity analyses after exclusion of studies which did not mandate 12-month DAPT for the outcomes of MI and ST did not change the magnitude or direction of the estimates.

\section{Myocardial infarction}

Twenty-one studies were included in MI analysis in the short term. EES significantly reduced the odds of MI compared with PES: OR 0.55 (95\% CI 0.40 to 0.76 ) $\mathrm{p}=0.0003$. In the overall class comparison, secondgeneration DES were associated with a $23 \%$ reduction of odds of MI OR 0.77 (95\% CI 0.65 to 0.91$) \mathrm{p}=0.002$ in the short term. A borderline significant class effect favouring 


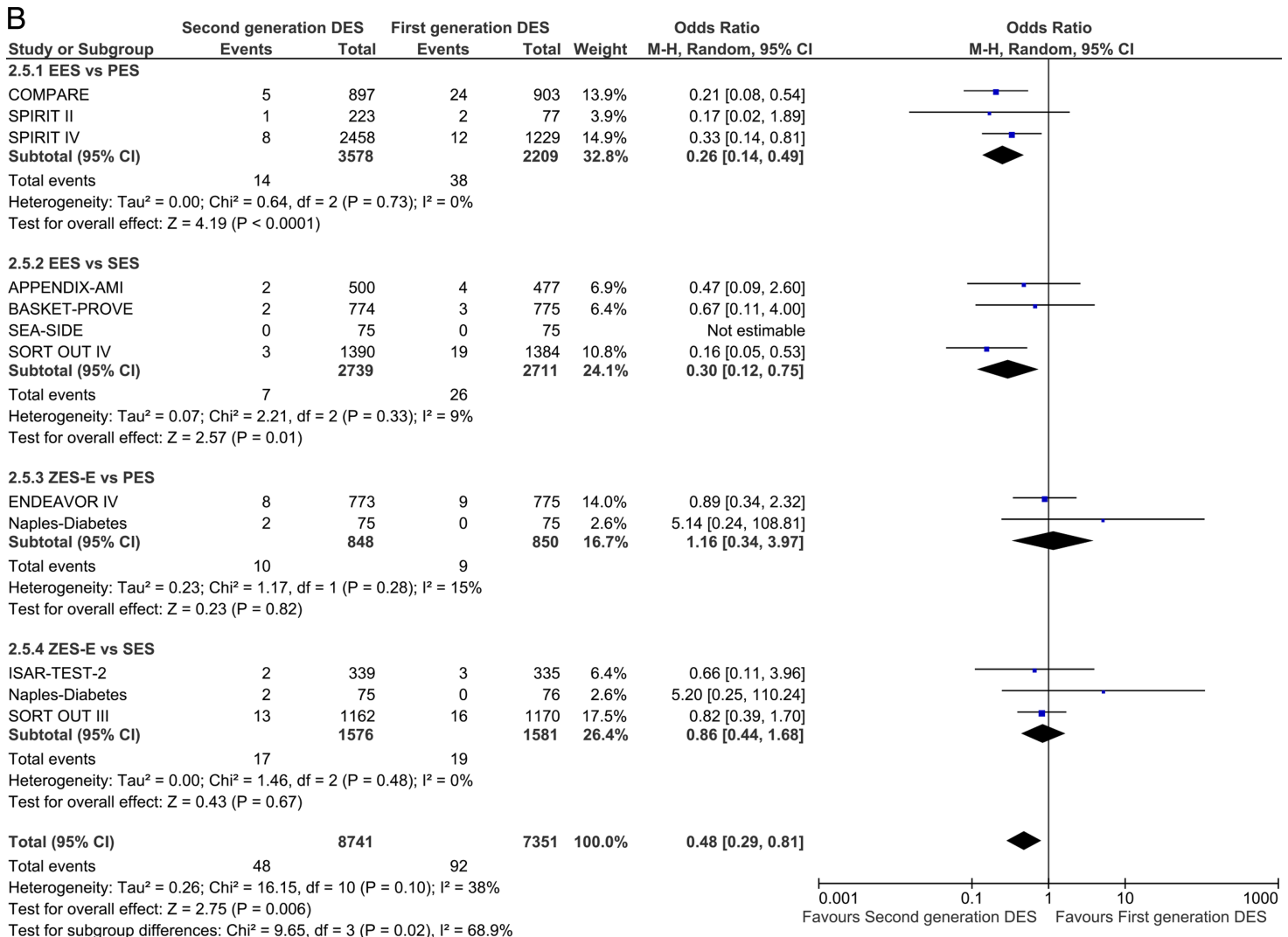

second-generation DES was sustained in the long-term analysis: OR 0.75 (95\% CI 0.55 to 1.01 ) $\mathrm{p}=0.06$, with odds of MI roughly halved in comparison with EES versus PES: OR 0.56 (95\% CI 0.42 to 0.74$) \mathrm{p}<0.0001$.

\section{Stent thrombosis}

For the analysis of definite ST, 17 studies were included. In the short term, EES was associated with a significant reduction of odds of ST compared with PES and SES: OR 0.24 (95\% CI 0.12 to 0.50$) \mathrm{p}=0.0001$ and OR 0.46 $(95 \%$ CI 0.21 to 0.99$) \quad \mathrm{p}=0.05$, respectively. Second-generation ZES-E increased the odds of ST by $122 \%$ compared with first-generation SES: OR 2.10 (95\% CI 1.06 to 4.16$) \mathrm{p}=0.03$. Results in the long term confirmed the short-term follow-up findings; EES was associated with a more pronounced and significant reduction of odds of ST over time as compared with PES and SES: OR 0.20 (95\% CI 0.08 to 0.49$) \mathrm{p}=0.0004$ and OR $0.30(95 \%$ CI 0.12 to 0.75$) \mathrm{p}=0.01$, respectively.

\section{DISCUSSION}

The present study is the largest report so far comparing first-generation versus second-generation DES. With 31379 patients included, it provides the most comprehensive overview on the safety and efficacy outcomes of different first-generation and second-generation stents. The main findings of this meta-analysis are as follows:
(1) second-generation EES and ZES significantly reduced the incidence of MI compared with firstgeneration PES; (2) only second-generation EES significantly reduced the odds of definite and definite/probable ST compared with first-generation DES (3) second-generation EES and ZES-R, and the firstgeneration SES, are similar to each other with regard to their efficacy and significantly better than ZES-E and PES with regard to repeat coronary revascularisations.

In the present large-scale study analysis, single and composite safety end points did not differ in direction or magnitude of the effect favouring durable polymer EES.

\section{Safety}

First-generation DES have been found to be superior to BMS in reducing restenosis and the need for repeat revascularisation. Their performance in terms of safety, and strictly, increased propensity for late and very late thrombotic events, however, was questioned as long follow-up data were becoming available; further studies showed that late and very late stent thrombosis could be attributed to numerous complex mechanisms with device designrelated factors being of paramount importance. ${ }^{4}$ The inflammation induced by the durable polymers of firstgeneration DES may result in delayed healing and incomplete covering of stent struts by new and functional endothelium, with uncovered stent struts serving as a source 


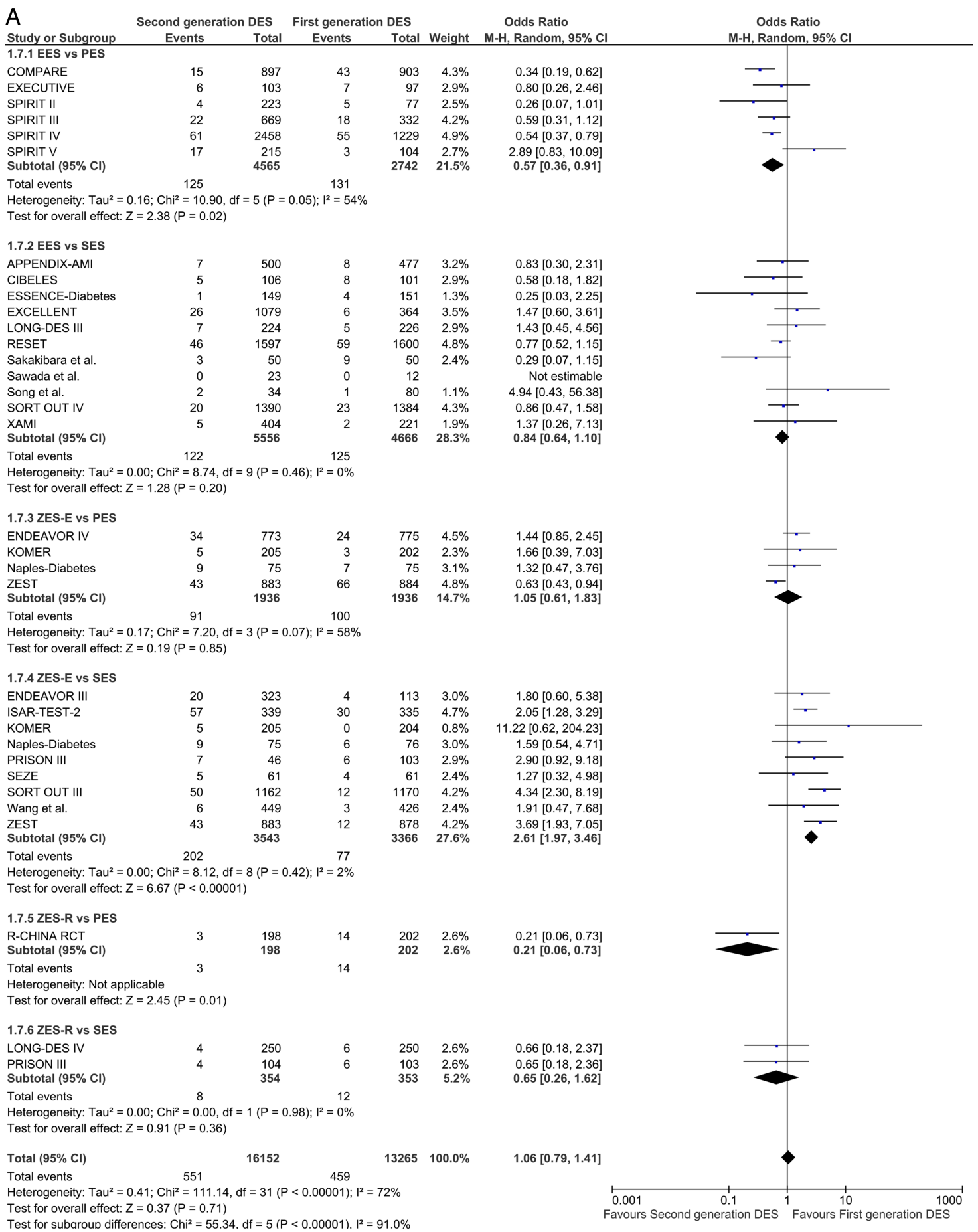

Figure 5 Analysis of TLR at short-term (A) and long-term (B) follow-up. ORs and 95\% Cls. Size of squares is proportional to the statistical weight of each trial. TLR, target lesion revascularisation.

for future episodes of ST; second, other factors such as stent malapposition, mechanical tissue injury caused by stent struts during implantation and finally, polymer hypersensitivity or even toxicity, as is the case for PES, ${ }^{58}$ in turn associated with persistent fibrin deposition, might also play a potential role. Second-generation DES were introduced to address the concerns raised by first generation DES by either optimising their metallic stent platform or polymer and eluted drug; that is, secondgeneration EES uses thin struts coated with durable, fluorinated polymer, which has been shown to have thromboresistant properties in experimental studies; similarly, ZES-R combined more rapid elution kinetics than sirolimus (SES) in the same time offering thinner, more biocompatible phosphorylcholine polymer placed on a cobalt alloy stent platform. ${ }^{7}$ 


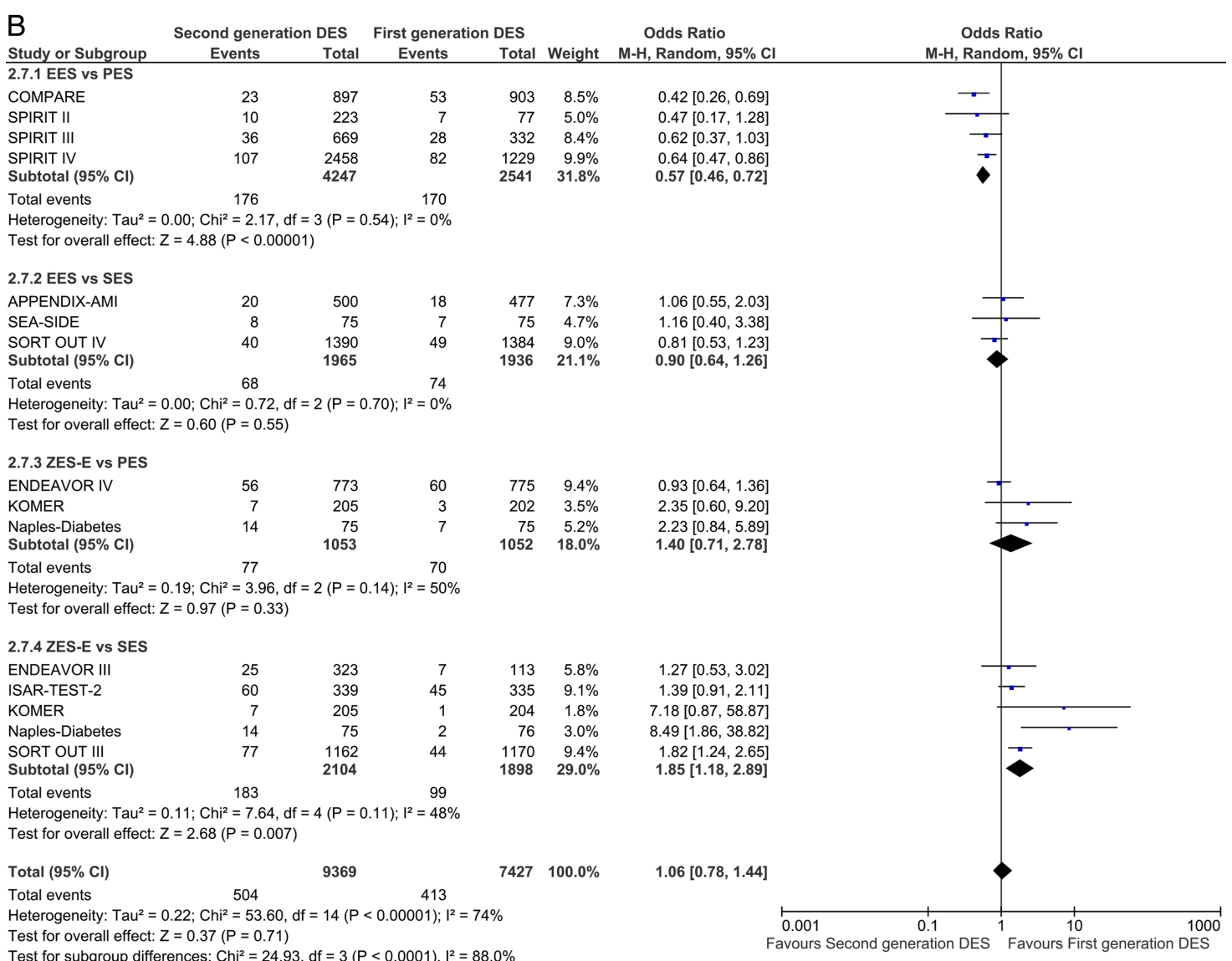

\section{Figure 5 Continued}

In the present meta-analysis, which compared most robust evidence of first-generation versus secondgeneration DES data, second-generation EES was found to be superior in regard to safety end points as compared with first-generation PES but not SES; this might be attributed to the proven overdose and/or accumulation of paclitaxel in the arterial wall due to a coronary uptake, in turn leading to toxicity, inflammation and late in-stent stenosis, which is not the case with SES. ${ }^{59}$ The superiority of thin strut EES and ZES in reducing the incidence of MI in the short clinical follow-up might also come from mechanistic reasons; indeed, this might be related to the more frequent side branch jailing with thick strut devices (SES Cypher $140 \mu \mathrm{m}$ and PES Taxus Express $134 \mu$ vs ZES Endeavor/Resolute $91 \mu \mathrm{m}$ and Abbott Xience V $81 \mu \mathrm{m}$ ), resulting in turn in higher rates of periprocedural MI. ${ }^{60-62}$ Although ST should be considered a surrogate safety end point, which must be interpreted in perspective of MI and mortality, it remains a devastating complication and is often associated with high rates of mortality and morbidity. Second-generation EES was associated with significantly lower rates of definite and definite or probable ST in short-term analysis compared with first-generation DES; this finding is in line with a meta-analysis by Palmerini, ${ }^{5}$ which for the first time demonstrated the superiority of EES over BMS and first-generation and secondgeneration DES in reducing early (0-30 days) and late
(31 days-12 months) ST. This analysis integrates the most updated data and enriches the previous findings of longer follow-up clinical data for particular devices, demonstrating for the first time that EES reduces definite and definite or probable ST also beyond these time frames (very late ST) compared with first-generation DES. Notably, data on EES do not reflect the performance of second-generation ZES-E in terms of stent thrombosis; indeed, Endeavor was found to even increase the incidence of definite ST as compared with SES at $\leq 1$ year, mainly driven by the results of the SORT OUT III $^{42}$ and $\mathrm{ZEST}^{55}$ trials. As zotarolimus is a synthetic analogue of sirolimus, the disparities between stents are attributed to different kinetics of drug release from the polymers used for drug elution (1 week with ZES and 3 months with SES); postulated quick zotarolimus release and high initial concentrations not only affect the healing of the plaque and arterial wall, but may also allow for exposure of the atheromatous debris to the bloodstream, thus increasing the risk of early ST, which is of particular importance in high-risk patients with acute coronary syndrome or multivessel disease.

\section{Efficacy and MACE}

Design-related factors such as strut thickness, type of antiproliferative agent, drug elution kinetics, elution time and type of polymer are all factors that may as well impact 


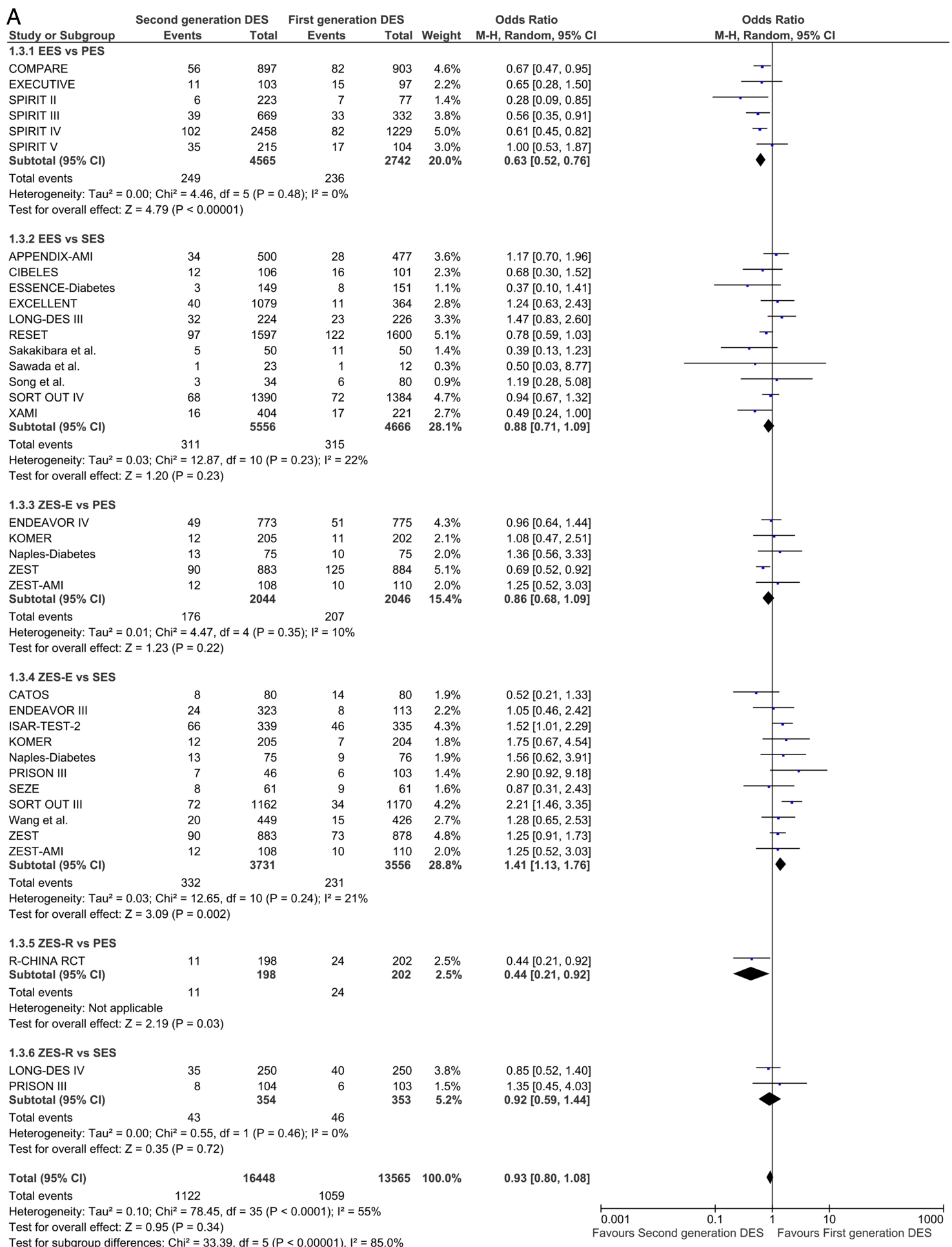

Figure 6 Analysis of MACE at short-term (A) and long-term (B) follow-up. ORs and 95\% Cls. Size of squares is proportional to the statistical weight of each trial. MACE, major adverse cardiovascular events.

efficacy outcomes ${ }^{63}$; although not a new finding, in this analysis all limus-eluting DES, with the exception of ZES-E, were associated with significantly lower rates of TLR/TVR than the first-generation PES. Taken together, inflammation causing properties of paclitaxel along with the short release curve of ZES-E preclude optimal suppression of procedure related injury responses, in turn resulting in subsequent intimal hyperplasia and increased need for repeat revascularisation. ${ }^{64}$ Unlike ZES-E, the more recently introduced ZES-R, which has a much longer (up to 180 days) release curve of the same antiproliferative agent, zotarolimus, is associated with a significant reduction in TVR/TLR compared with ZES-E. ${ }^{65}$

In the present paper, we additionally analysed the incidence of MACE, which to the best of our knowledge is the most proper measure of device performance, as it 


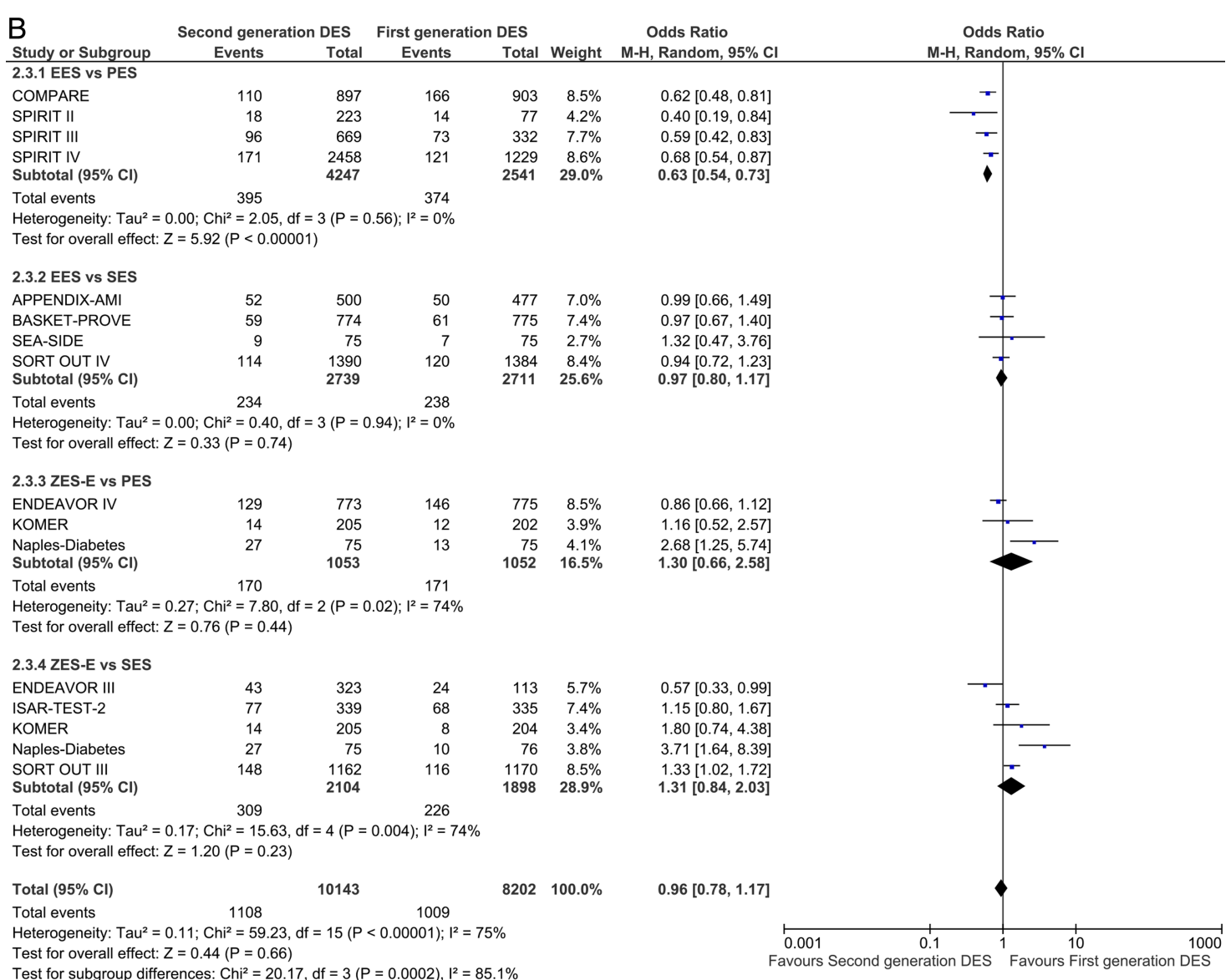

Figure 6 Continued

takes into account both safety and efficacy outcomes, providing statistical power given the low numbers of single outcome events. Not surprisingly, MACE analysis confirmed the single-outcome findings, with secondgeneration EES outperforming first-generation PES at $\leq 1$ year and beyond. Remarkably, the initial short-term benefit of SES over ZES-E, attributable mainly to higher rates of repeat revascularisation with the latter, becomes less pronounced at long-term follow-up when drug elution is over.

\section{Limitations}

As with any meta-analysis, our study shares the limitations of the original studies. Results were analysed on trial level data, and therefore we could not assess whether all baseline characteristics were balanced among groups (although for the most part they were balanced within each RCT). Data for follow-ups longer than 1 year are limited but appear to confirm the direction of the estimates at $\leq 1$-year. The patient inclusion criteria of this meta-analysis are broad, more closely reflecting current practice, comprising stable and unstable high-risk patients. Potentially heterogeneous definitions of MI used across the trials may represent another limitation.

Another aspect is the duration of dual antiplatelet therapy (DAPT), that is, the combination of aspirin and a P2Y12 receptor blocker, which varied among the different trials. The variability of DAPT may, however, be less important in the context of the present meta-analysis given that BMS were excluded and most trials employed at least 6 months DAPT duration. Owing to the limited number of trials comparing ZES-R to first-generation DES, the findings with this device should be viewed as exploratory but certainly deserve further attention. Despite these limitations, this meta-analysis provides the largest-scale comparative information on the efficacy and safety profiles of different DES in current clinical practice.

\section{CONCLUSIONS}

Second-generation EES and ZES-R offer a similar level of efficacy compared with first-generation SES, but are more effective than PES; however, only secondgeneration EES significantly reduced the incidence of both MI and ST and therefore should be perceived as the safest DES to date.

\section{Author affiliations}

${ }^{1}$ Invasive Cardiology, National Research Council Institute of Clinical Physiology (CNR-IFC), Pisa, Italy

${ }^{2}$ Department of Internal Medicine, Division of Cardiology, Pulmonology and Vascular Medicine, Heinrich-Heine-University, Düsseldorf, Germany

${ }^{3} 10$ th Military Research Hospital and Polyclinic, Bydgoszcz, Poland 
${ }^{4}$ Piedmont Heart Institute, Atlanta, Georgia, USA

${ }^{5}$ Department of Cardiology, Yale Medical School, New Haven, Connecticut, USA

${ }^{6} 1$ st Department of Cardiology, Teaching Hospital, Medical University of Warsaw, Warsaw, Poland

${ }^{7}$ Division of Cardiology, MedStar Washington Hospital Center, Washington DC, USA

${ }^{8}$ Department of Cardiology, Ospedali Riuniti di Bergamo, Bergamo, Italy ${ }^{9}$ Department of Cardiology, Ospedale della Misericordia, Grosseto, Italy

${ }^{10}$ Department of Cardiology, Onze Lieve Vrouwe Gasthuis, Amsterdam, The Netherland

${ }^{11}$ Department of Cardiology and Internal Medicine, Ludwik Rydygier Collegium Medicum, Nicolaus Copernicus University, Bydgoszcz, Poland ${ }^{12}$ Department of Cardiology, Radboud University Nijmegen Medical Center, Nijmegen, The Netherlands

${ }^{13}$ Systematic Investigation and Research on Interventions and Outcomes (SIRIO) MEDICINE Research Network

Contributors All authors contributed to the present article. MK, BG and LK were responsible for data search and abstraction and critical analysis of eligibility. EPN and MK drafted the manuscript. DK, AL, RW, SB, GM, UL, RJvS, JK, and HS critically revised the manuscript.

Competing interests DK has received research/grant support from Boston Scientific, Medtronic, and Abbott Vascular and has served as consultant for Boston Scientific, Medtronic, and Micell Technologies; all the remaining authors do not have any conflicts relevant to this contribution.

Provenance and peer review Not commissioned; externally peer reviewed.

Open Access This is an Open Access article distributed in accordance with the Creative Commons Attribution Non Commercial (CC BY-NC 3.0) license, which permits others to distribute, remix, adapt, build upon this work noncommercially, and license their derivative works on different terms, provided the original work is properly cited and the use is non-commercial. See: http:// creativecommons.org/licenses/by-nc/3.0/

\section{REFERENCES}

1. Greenhalgh J, Hockenhull J, Rao N, et al. Drug-eluting stents versus bare metal stents for angina or acute coronary syndromes. Cochrane Database Syst Rev 2010;(5):CD004587.

2. Camenzind E, Steg PG, Wijns W. Stent thrombosis late after implantation of first-generation drug-eluting stents: a cause for concern. Circulation 2007;115:1440-55; discussion 1455.

3. Daemen J, Wenaweser P, Tsuchida K, et al. Early and late coronary stent thrombosis of sirolimus-eluting and paclitaxel-eluting stents in routine clinical practice: data from a large two-institutional cohort study. Lancet 2007;369:667-78.

4. Joner M, Finn AV, Farb A, et al. Pathology of drug-eluting stents in humans: delayed healing and late thrombotic risk. J Am Coll Cardiol 2006;48:193-202.

5. Navarese EP, Tandjung K, Claessen B, et al. Safety and efficacy outcomes of first and second generation durable polymer drug eluting stents and biodegradable polymer biolimus eluting stents in clinical practice: comprehensive network meta-analysis. BMJ 2013;347:f6530.

6. Sethi A, Bahekar A, Bhuriya R, et al. Zotarolimus-eluting stent versus sirolimus-eluting and paclitaxel-eluting stents for percutaneous coronary intervention: a meta-analysis of randomized trials. Arch Cardiovasc Dis 2012;105:544-56.

7. Fan J, Du H, Yin Y, et al. Efficacy and safety of zotarolimus-eluting stents compared with sirolimus-eluting stents in patients undergoing percutaneous coronary interventions-a meta-analysis of randomized controlled trials. Int J Cardiol 2013;167:2126-33.

8. Park KW, Kang SH, Velders MA, et al. Safety and efficacy of everolimus- versus sirolimus-eluting stents: a systematic review and meta-analysis of 11 randomized trials. Am Heart $J$ 2013;165:241-50 e4

9. Liberati A, Altman DG, Tetzlaff J, et al. The PRISMA statement for reporting systematic reviews and meta-analyses of studies that evaluate health care interventions: explanation and elaboration. Ann Intern Med 2009;151:W65-94.

10. Cutlip DE, Windecker S, Mehran R, et al. Clinical end points in coronary stent trials: a case for standardized definitions. Circulation 2007:115:2344-51.
11. Higgins JP, Thompson SG, Deeks JJ, et al. Measuring inconsistency in meta-analyses. BMJ 2003;327:557-60.

12. Fleiss JL. Analysis of data from multiclinic trials. Control Clin Trials 1986:7:267-75.

13. Velders MA, Boven AJV, Hofma SH. Xience V stent vs. Cypher stent in all-comer patients: a randomized trial. Unpublished Work, 2012.

14. Velders MA, Hofma SH, Brouwer J, et al. Two-year results of an open-label randomized comparison of everolimus-eluting stents and sirolimus-eluting stents. PLOS ONE 2013;8:e64424.

15. Kaiser C, Galatius S, Erne P, et al. Drug-eluting versus bare-metal stents in large coronary arteries. $N$ Engl J Med 2010;363:2310-19.

16. Park HJ, Kim HY, Lee JM, et al. Randomized comparison of the efficacy and safety of zotarolimus-eluting stents vs. sirolimus-eluting stents for percutaneous coronary intervention in chronic total occlusion-CAtholic Total Occlusion Study (CATOS) trial. Circ J 2012;76:868-75.

17. Moreno R, Garcia E, Teles R, et al. Randomized comparison of sirolimus-eluting and everolimus-eluting coronary stents in the treatment of total coronary occlusions: results from the chronic coronary occlusion treated by everolimus-eluting stent randomized trial. Circ Cardiovasc Interv 2013;6:21-8

18. Kedhi E, Joesoef KS, McFadden E, et al. Second-generation everolimus-eluting and paclitaxel-eluting stents in real-life practice (COMPARE): a randomised trial. Lancet 2010;375:201-9.

19. Smits PC, Kedhi E, Royaards KJ, et al. 2-year follow-up of a randomized controlled trial of everolimus- and paclitaxel-eluting stents for coronary revascularization in daily practice. COMPARE (Comparison of the everolimus eluting XIENCE-V stent with the paclitaxel eluting TAXUS LIBERTE stent in all-comers: a randomized open label trial). J Am Coll Cardiol 2011;58:11-18.

20. http://www.medscape.com/viewarticle/714902 (accessed Jan 2014).

21. Kandzari DE, Leon MB, Popma JJ, et al. Comparison of zotarolimus-eluting and sirolimus eluting stents in patients with native coronary artery disease: a randomized controlled trial. J Am Coll Cardiol 2006;48:2440-7.

22. Kandzari DE, Mauri L, Popma JJ, et al. Late-term clinical outcomes with zotarolimus- and sirolimus-eluting stents. 5-year follow-up of the ENDEAVOR III (A Randomized Controlled Trial of the Medtronic Endeavor Drug [ABT-578] Eluting Coronary Stent System Versus the Cypher Sirolimus-Eluting Coronary Stent System in De Novo Native Coronary Artery Lesions). JACC Cardiovasc Inter 2011;4:543-50.

23. Leon MB, Mauri L, Popma JJ, et al. A randomized comparison of the Endeavor zotarolimus-eluting stent versus the TAXUS paclitaxel-eluting stent in de novo native coronary lesions 12-month outcomes from the ENDEAVOR IV trial. J Am Coll Cardiol 2010;55:543-54.

24. Kirtane AJ, Leon MB, Ball MW, et al. The "final" 5-year follow-up from the ENDEAVOR IV trial comparing a zotarolimus-eluting stent with a paclitaxel-eluting stent. JACC Cardiovasc Interv 2013;6:325-33.

25. Kim WJ, Lee SW, Park SW, et al. Randomized comparison of everolimus-eluting stent versus sirolimus-eluting stent implantation for de novo coronary artery disease in patients with diabetes mellitus (ESSENCE-DIABETES): results from the ESSENCE-DIABETES trial. Circulation 2011;124:886-92.

26. Park KW, Chae IH, Lim DS, et al. Everolimus-eluting versus sirolimus-eluting stents in patients undergoing percutaneous coronary intervention: the EXCELLENT (Efficacy of Xience/Promus Versus Cypher to Reduce Late Loss After Stenting) randomized trial. J Am Coll Cardiol 2011;58:1844-54.

27. Ribichini F, Romano M, Rosiello R, et al. A Clinical and Angiographic Study of the XIENCE V Everolimus-Eluting Coronary Stent System in the Treatment of Patients With Multivessel Coronary Artery Disease: The EXECUTIVE Trial (EXecutive RCT: Evaluating XIENCE V in a Multi Vessel Disease). JACC Cardiovasc Interv 2013;6:1012-22.

28. Byrne RA, Mehilli J, lijima R, et al. A polymer-free dual drug-eluting stent in patients with coronary artery disease: a randomized trial vs. polymer-based drug-eluting stents. Eur Heart J 2009;30:923-31.

29. Byrne RA, Kastrati A, Tiroch K, et al. 2-year clinical and angiographic outcomes from a randomized trial of polymer-free dual drug-eluting stents versus polymer-based Cypher and Endeavor [corrected] drug-eluting stents. J Am Coll Cardiol 2010;55:2536-43.

30. Kang WC, Ahn T, Lee K, et al. Comparison of zotarolimus-eluting stents versus sirolimus-eluting stents versus paclitaxel-eluting stents for primary percutaneous coronary intervention in patients with ST-elevation myocardial infarction: results from the Korean Multicentre Endeavor (KOMER) acute myocardial infarction (AMI) trial. Eurolntervention 2011;7:936-43. 
31. Park DW, Kim YH, Song HG et al. Comparison of everolimus- and sirolimus-eluting stents in patients with long coronary artery lesions: a randomized LONG-DES-III (Percutaneous Treatment of LONG Native Coronary Lesions With Drug-Eluting Stent-III) Trial. JACC Cardiovasc Interv 2011;4:1096-103.

32. Ahn JM, Park DW, Kim YH, et al. Comparison of resolute zotarolimus-eluting stents and sirolimus-eluting stents in patients with de novo long coronary artery lesions: a randomized LONG-DES IV trial. Circ Cardiovasc Interv 2012;5:633-40.

33. Briguori C, Airoldi F, Visconti G, et al. Novel approaches for preventing or limiting events in diabetic patients (Naples-diabetes) trial: a randomized comparison of 3 drug-eluting stents in diabetic patients. Circ Cardiovasc Interv 2011;4:121-9.

34. Van den Branden BJ, Teeuwen K, Koolen JJ, et al. Primary Stenting of Totally Occluded Native Coronary Arteries III (PRISON III): a randomised comparison of sirolimus-eluting stent implantation with zotarolimus-eluting stent implantation for the treatment of total coronary occlusions. Eurolntervention 2013;9:841-53.

35. Xu B, Yang Y, Yuan Z, et al. Zotarolimus- and paclitaxel-eluting stents in an all-comer population in China: the RESOLUTE China randomized controlled trial. JACC Cardiovasc Interv 2013;6:664-70.

36. Kimura T, Morimoto T, Natsuaki M, et al. Comparison of everolimus-eluting and sirolimus-eluting coronary stents: 1 -year outcomes from the Randomized Evaluation of Sirolimus-eluting Versus Everolimus-eluting stent Trial (RESET). Circulation 2012;126:1225-36.

37. Sakakibara $\mathrm{T}$, Ishii $\mathrm{H}$, Toriyama $\mathrm{T}$, et al. Sirolimus-eluting stent vs. everolimus-eluting stent for coronary intervention in patients on chronic hemodialysis. Circ J 2012;76:351-5.

38. Sawada T, Shinke T, Otake H, et al. Comparisons of detailed arterial healing response at seven months following implantation of an everolimus- or sirolimus-eluting stent in patients with ST-segment elevation myocardial infarction. Int J Cardiol 2013;168:960-6.

39. Burzotta F, Trani C, Todaro D, et al. Prospective randomized comparison of sirolimus- or everolimus-eluting stent to treat bifurcated lesions by provisional approach. JACC Cardiovasc Interv 2011;4:327-35

40. Chung WY, Kang J, Cho YS, et al. A randomized, prospective, two-center comparison of sirolimus-eluting stent and zotarolimus-eluting stent in acute ST-elevation myocardial infarction the SEZE trial. Chin Med J 2012;125:3373-81.

41. Song HG, Park DW, Kim YH, et al. Randomized trial of optimal treatment strategies for in-stent restenosis after drug-eluting stent implantation. J Am Coll Cardiol 2012;59:1093-100.

42. Rasmussen K, Maeng M, Kaltoft A, et al. Efficacy and safety of zotarolimus-eluting and sirolimus-eluting coronary stents in routine clinical care (SORT OUT III): a randomised controlled superiority trial. Lancet 2010;375:1090-9.

43. Maeng M, Tilsted HH, Jensen LO, et al. 3-Year clinical outcomes in the randomized SORT OUT III superiority trial comparing zotarolimus- and sirolimus-eluting coronary stents. JACC CardiovasC Interv 2012:5:812-18.

44. Jensen LO, Thayssen P, Hansen HS, et al. Randomized comparison of everolimus-eluting and sirolimus-eluting stents in patients treated with percutaneous coronary intervention: the Scandinavian Organization for Randomized Trials with Clinical Outcome IV (SORT OUT IV). Circulation 2012;125:1246-55.

45. Jensen LO, Thayssen P, Christiansen EH, et al. 2-year patient-related versus stent-related outcomes: the SORT OUT IV (Scandinavian Organization for Randomized Trials With Clinical Outcome IV) Trial. J Am Coll Cardiol 2012;60:1140-7.

46. Serruys PW, Ruygrok $\mathrm{P}$, Neuzner J, et al. A randomised comparison of an everolimus-eluting coronary stent with a paclitaxel-eluting coronary stent:the SPIRIT II trial. EuroIntervention 2006;2:286-94.

47. Onuma $\mathrm{Y}$, Miquel-Hebert $\mathrm{K}$, Serruys PW, et al. Five-year long-term clinical follow-up of the XIENCE V everolimus-eluting coronary stent system in the treatment of patients with de novo coronary artery disease: the SPIRIT II trial. Eurolntervention 2013;8:1047-51.

48. Stone GW, Midei M, Newman W, et al. Comparison of an everolimus-eluting stent and a paclitaxel-eluting stent in patients with coronary artery disease: a randomized trial. JAMA 2008;299:1903-13.

49. Applegate RJ, Yaqub M, Hermiller JB, et al. Long-term (three-year) safety and efficacy of everolimus-eluting stents compared to paclitaxel-eluting stents (from the SPIRIT III Trial). Am J Cardiol 2011;107:833-40.

50. Stone GW, Rizvi A, Newman W, et al. Everolimus-eluting versus paclitaxel-eluting stents in coronary artery disease. $N$ Engl J Med 2010;362:1663-74.

51. Stone GW, Rizvi A, Sudhir K, et al. Randomized comparison of everolimus- and paclitaxel-eluting stents. 2-year follow-up from the SPIRIT (Clinical Evaluation of the XIENCE V Everolimus Eluting Coronary Stent System) IV trial. J Am Coll Cardiol 2011;58:19-25.

52. Grube E, Chevalier B, Guagliumi G, et al. The SPIRIT V diabetic study: a randomized clinical evaluation of the XIENCE $V$ everolimus-eluting stent vs the TAXUS Liberte paclitaxel-eluting stent in diabetic patients with de novo coronary artery lesions. Am Heart J 2012;163:867-75 e1.

53. Wang L, Zhang D, Yang X, et al. Comparison of safety and efficacy of Cypher $\AA$ stent and Endeavor $($ stent in patients with acute ST elevation myocardial infarction (STEMI) undergoing emergency $\mathrm{PCI}$. J Am Coll Cardiol 2011;58:B216 (Abstract).

54. Hofma SH, Brouwer J, Velders MA, et al. Second-generation everolimus-eluting stents versus first-generation sirolimus-eluting stents in acute myocardial infarction. 1-year results of the randomized XAMI (XienceV Stent vs. Cypher Stent in Primary PCI for Acute Myocardial Infarction) trial. J Am Coll Cardiol 2012;60:381-7.

55. Park DW, Kim YH, Yun SC, et al. Comparison of zotarolimus-eluting stents with sirolimus- and paclitaxel-eluting stents for coronary revascularization: the ZEST (comparison of the efficacy and safety of zotarolimus-eluting stent with sirolimus-eluting and paclitaxel-eluting stent for coronary lesions) randomized trial. J Am Coll Cardiol 2010;56:1187-95.

56. Lee CW, Park DW, Lee SH, et al. Comparison of the efficacy and safety of zotarolimus-, sirolimus-, and paclitaxel-eluting stents in patients with ST-elevation myocardial infarction. Am J Cardiol 2009;104:1370-6.

57. http://www.trialresultscenter.org/study8670-ZEST-AMI-(vs-SES).htm; http://www.trialresultscenter.org/study8670-ZEST-AMI-(vs-PES).htm (accessed Jan 2014)

58. Radeleff B, Lopez-Benitez R, Stampfl U, et al. Paclitaxel-induced arterial wall toxicity and inflammation: tissue uptake in various dose densities in a minipig model. $J$ Vasc Interv Radiol 2010;21:1262-70.

59. Stampfl U, Radeleff B, Sommer C, et al. Paclitaxel-induced arterial wall toxicity and inflammation: part 2-long-term tissue response in a minipig model. J Vasc Interv Radiol 2009;20:1608-16.

60. Applegate R, Hermiller J, Williams $\mathrm{J}$, et al. Evaluation of the effects of everolimus-eluting and paclitaxel-eluting stents on target lesions with jailed side branches: 2-year results from the SPIRIT III randomized trial. Catheter Cardiovasc Interv 2010;76:644-51.

61. Joner M, Nakazawa G, Finn AV, et al. Endothelial cell recovery between comparator polymer-based drug-eluting stents. J Am Coll Cardiol 2008;52:333-42.

62. Nakatani S, Nishino M, Taniike M, et al. Initial findings of impact of strut width on stent coverage and apposition of sirolimus-eluting stents assessed by optical coherence tomography. Catheter Cardiovasc Interv 2013;81:776-81.

63. Hausleiter J, Kastrati A, Mehilli J, et al. Impact of lesion complexity on the capacity of a trial to detect differences in stent performance: results from the ISAR-STEREO trial. Am Heart $J$ 2003;146:882-6.

64. Nakazawa G, Finn AV, John MC, et al. The significance of preclinical evaluation of sirolimus-, paclitaxel-, and zotarolimus-eluting stents. Am J Cardiol 2007;100:36M-44M.

65. Silber S, Windecker S, Vranckx $\mathrm{P}$, et al. Unrestricted randomised use of two new generation drug-eluting coronary stents: 2-year patient-related versus stent-related outcomes from the RESOLUTE All Comers trial. Lancet 2011;377:1241-7. 